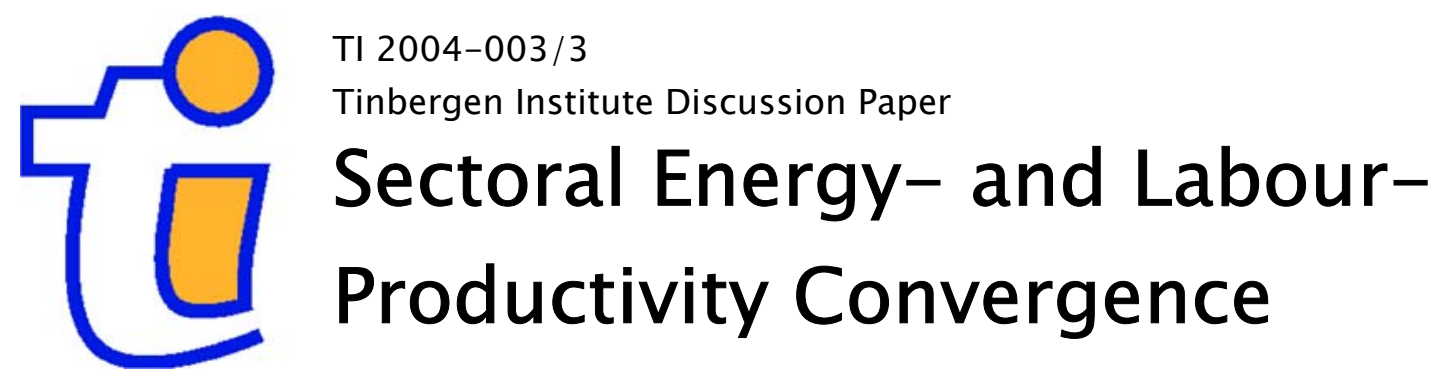

Peter Muldera

Henri L.F. de Grootb

a International Institute for Applied Systems Analysis, Laxenburg, Austria,

b Faculty of Economics and Business Administration, Vrije Universiteit Amsterdam, and Tinbergen Institute. 


\section{Tinbergen Institute}

The Tinbergen Institute is the institute for economic research of the Erasmus Universiteit Rotterdam, Universiteit van Amsterdam, and Vrije Universiteit Amsterdam.

Tinbergen Institute Amsterdam

Roetersstraat 31

1018 WB Amsterdam

The Netherlands

Tel.: $\quad+31(0) 205513500$

Fax: $\quad+31(0) 205513555$

Tinbergen Institute Rotterdam

Burg. Oudlaan 50

3062 PA Rotterdam

The Netherlands

Tel.: $\quad+31(0) 104088900$

Fax: $\quad+31(0) 104089031$

Please send questions and/or remarks of nonscientific nature to driessen@tinbergen.nl.

Most TI discussion papers can be downloaded at http://www.tinbergen.nl. 


\title{
Sectoral Energy- and Labour-Productivity Convergence
}

\author{
Peter Mulder ${ }^{\mathrm{a}}$ and Henri L.F. de Groot ${ }^{\mathrm{b} 1}$ \\ ${ }^{a}$ International Institute for Applied Systems Analysis, A-2361 Laxenburg, Austria \\ ${ }^{b}$ Dept. of Spatial Economics, Vrije Universiteit and Tinbergen Institute \\ De Boelelaan 1105, 1081 HV Amsterdam, The Netherlands
}

\begin{abstract}
This paper provides an empirical analysis of energy- and labour-productivity convergence at a detailed sectoral level for 14 OECD countries, covering the period 1970-1997. A $\sigma-$ convergence analysis shows that the development of cross-country variation in productivity performance depends on the level of aggregation. Both patterns of convergence as well as divergence are found. A $\beta$-convergence analysis provides support for the hypothesis that in most sectors lagging countries tend to catch up with technological leaders, in particular in terms of energy productivity. Moreover, the results show that convergence is conditional rather than unconditional, meaning that productivity levels converge to country-specific steady states, and that cross-country differences of energy-productivity levels are substantially larger than of labour-productivity levels at all levels of sectoral aggregation. Finally, searching for the fundamentals determining cross-country productivity differentials reveals a positive productivity effect of energy prices and economies of scale in several sectors, while wages, investment share, openness and specialization play only a very limited role in explaining (cross-country differences in) energy- and labour-productivity growth.
\end{abstract}

Keywords: energy productivity, labour productivity, convergence, sectoral analysis JEL codes: O13, O47, O5, Q43

\footnotetext{
${ }^{1}$ Corresponding author: Henri L.F. de Groot, Dept. of Spatial Economics, Vrije Universiteit, De Boelelaan 1105, 1081 HV Amsterdam, the Netherlands, email hgroot@ feweb.vu.nl, tel. +31 20444 6168, fax. +31 20444 6004. We gratefully acknowledge useful comments by Jeroen van den Bergh, Kornelis Blok, Reyer Gerlagh, Ton Manders, Hein Mannaerts, Machiel Mulder, Sjak Smulders, Paul Tang and Herman Vollebergh on earlier versions of this paper. Financial support of NWO as well as the hospitality of CPB Netherlands Bureau for Economic Policy Analysis is gratefully acknowledged.
} 


\section{INTRODUCTION}

Economies differ, and so does productivity performance. Of course, economies also interact and, hence, productivity developments are thought to be determined not only by developments within a particular country or sector, but also by what is happening in the outside world. Therefore, a key issue in understanding long-run productivity performance is whether the process of economic growth tends to involve reductions in productivity differences among countries, for example, due to capital accumulation or technology transfers. The introduction of new or endogenous growth theories has generated renewed interest in this question and has induced a wave of empirical research on cross-country convergence of per capita income as well as of labour productivity or total factor productivity (e.g., Barro and Sala-i-Martin 1992, Mankiw et al. 1992, Islam 1995). This issue obviously bears important implications for the international welfare distribution. At the same time, over the last decades increasing attention is paid to the role of energy in production processes and economic growth. Energy consumption is an important source of greenhouse gas emissions. Most governments in OECD countries explicitly recognize the need for sustainable development and aim at a decoupling of economic growth and environmental pressure. In a more operational sense this implies that not only labour productivity, but also energy productivity have to increase. Consequently, important questions arise concerning the dynamics of cross-country differences of energy- and labour productivity. Are these differences decreasing, or is the gap between leading and backward countries getting larger? Does energy-productivity convergence follow patterns of labour-productivity convergence? Do relatively inefficient countries catch-up with technological 'leaders'? And if so, how quickly and by what means? Do convergence patterns differ substantially across sectors? We will answer these questions by simultaneously carrying out an empirical analysis of crosscountry energy- and labour-productivity convergence at a detailed sector level, using a new dataset that merges energy data and economic data for 13 sectors and 14 OECD countries, covering the period 1970-1997.

In several respects, our paper differs from previous empirical research on crosscountry convergence. By including energy-productivity developments, our analysis differs from the empirical macroeconomic convergence literature that focuses on convergence of per capita income, labour productivity and total factor productivity. Moreover, in spite of many existing cross-country studies on energy-productivity or energy-intensity developments and its determinants (e.g., Howarth et al., 1991; Miketa, 2001; Schipper and Meyers, 1992; 
Unander et al., 1999; Mulder and De Groot 2003), to the best of our knowledge this literature lacks a systematic convergence analyses from a macroeconomic perspective. Hence, we add to the existing literature a systematic comparison of energy- and labour-productivity convergence. Finally, we do so at a detailed sectoral level. By looking at cross-country convergence patters within sectors, our analysis differs from virtually all convergence studies in the empirical growth literature, since they employ aggregated data. Important exceptions are sectoral studies by Dollar and Wolff $(1988,1993)$ and Bernard and Jones $(1996 a, b)$ who - using (partly) the same data source (OECD's ISDB) - conclude that a convergence analysis of aggregate productivity levels masks substantial differences at the sectoral level. An important underlying reason for this result is that productivity levels, measured as the ratio of value added over a unit of input (energy, labour), can substantially differ among sectors because some activities require inherently more capital, higher labour skills and/or technology than others. Aggregate productivity trends are therefore not directly attributable to technological change in individual sectors, as they can also be the result of changes in the distribution of production factors among sectors. Our sectoral approach corrects for most of the impact of such changes in the structure of production on aggregate productivity developments and, hence, establishes a closer link to issues concerning international convergence of technology driven productivity performance. Our analysis differs from the previously mentioned sectoral convergence analyses in comparing labour- and energyproductivity convergence, in further disaggregating the manufacturing sector into 10 subsectors, ${ }^{2}$ in using more recent data and in carrying out a more extensive search for countryand sector-specific factors to explain productivity convergence patterns.

The paper proceeds as follows. Section 2 contains a brief review of the convergence issue in the economic literature, in order to provide some theoretical background to our empirical analysis and to introduce several concepts used throughout the paper. Section 3 describes the data used. In section 4 we analyse the development of cross-country differences of energy- and labour-productivity levels within sectors over time. In section 5 we use a panel data approach to test the proposition that sectoral growth rates of energy- and labour productivity are inversely related to their initial levels of energy- and labour productivity, indicating possible patterns of catching-up. In addition, we try to identify the country- and

\footnotetext{
2 Although Dollar and Wolff $(1988,1993)$ distinguish 28 sectors, they only present a labour-productivity convergence indicator for a few years and did not perform a regression analysis to test for convergence patterns.
} 
sector specific fundamentals determining (differences in) energy- and labour productivity developments. Section 6 summarises and concludes.

\section{THE ISSUE OF CONVERGENCE}

The concept of productivity convergence has its roots in traditional neoclassical growth theory, with its central notion of a transitional growth path to a steady state. The Solow-Swan model (Solow 1956, Swan 1956) postulates convergence of per capita income, driven by the assumption of diminishing returns to capital accumulation at the economy-wide level. The dynamics of the model imply that initial differences in per capita income and capital endowments will vanish in the long run, due to declining growth rates as countries approach their steady state. In the steady state, diminishing returns are offset by technological progress, the principal source of long-run economic growth. The new or endogenous growth theory (Lucas 1988 and Romer 1986, 1990) yields a more diverse picture concerning patterns of convergence. In this view economic growth is ultimately driven by accumulation of knowledge or human capital, which is (at least partially) a public good. Hence, cross-country convergence depends on the extent of international knowledge spill-overs, allowing less productive countries to catch-up with more advanced economies. As such, endogenous growth theory supports the old hypothesis of the existence of an 'advantage of backwardness' (Gerschenkron 1952), suggesting that being relatively backward in productivity carries a potential for rapid advance (see, e.g., Abramovitz 1986). At the same time, endogenous growth theory suggests that growth differentials may persist or even increase: learning effects, externalities and market imperfections allow for economy-wide increasing returns to capital accumulation and the existence of multiple steady-states. A mixed view on convergence patterns also emerges if one takes into account the role of international trade: on the one hand trade will enhance cross-country convergence through knowledge diffusion and increasing competition, but on the other hand it may contribute to cross-country divergence since trade advances international specialization (e.g., Grossman and Helpman 1991).

These various approaches generated some degree of controversy around the issue of convergence and caused the convergence hypothesis to be the subject of extensive empirical research (see Islam 2003 for a recent survey). The stage for this convergence debate was set by Baumol (1986), who reported a strong negative relationship between the intial level of labour productivity and its subsequent growth over a long period (1870-1979), which he 
argued to be strong evidence in favour of convergence. Abramovitz (1986) presented similar evidence, arguing that catch-up growth has been most prominent in the period since 1945.

This position was challenged by DeLong (1988) who argued that Baumol's results suffered from a sample bias, in that his analysis has been confined to a sample of countries that have become rich and developed; if one takes a sample of countries that in 1870 seemed likely to converge, the evidence of convergence is less clear cut. In addition, a number of studies have presented evidence of income convergence across countries, by explicitly testing (augmented versions of) the Solow growth model (e.g., Barro 1991, Barro and Sala-i-Martin 1992, Mankiw et al. 1992, Islam 1995). These empirical cross-country growth analyses raised the important question of whether countries converge to a global or rather to a local steady state, the latter implying that convergence is conditional on cross-country differences in steadystate characteristics. They are, respectively, referred to as unconditional (or absolute) and conditional (or relative) convergence. This idea has been formalised by Durlauf and Johnson (1992) and confirmed by several studies in this field, some of them suggesting the existence of convergence clubs: groups of countries converging to different steady states (e.g., Chatterji 1992, Chatterji et al. 1993, Quah 1997). ${ }^{3}$

From this literature it follows that convergence can be understood in terms of levels and growth rates, which translates into a distinction between so-called $\sigma$-convergence and $\beta$ convergence (e.g., Barro 1991, Barro and Sala-i-Martin 1992). The former refers to a decreasing variance of cross-country differences in productivity levels, while the latter suggests a tendency of countries with relatively low initial productivity levels to grow relatively fast, building upon the proposition that growth rates tend to decline as countries approach their steady state. Obviously, $\sigma$-convergence and $\beta$-convergence are closely related. A narrowing dispersion of cross-country productivity differences implies that countries with a relatively poor initial productivity performance tend to grow relatively fast. However, as has been argued by Quah (1993), a statistically significant inverse relationship between the initial level and the growth rate of productivity performance can be consistent with constant or even increasing cross-country productivity differences - a phenomenon known as Galton's

\footnotetext{
${ }^{3}$ For more complete surveys of the convergence debate we refer to Barro and Sala-i-Martin (1995), Broadberry (1996), Durlauf and Quah (1999), Fagerberg (1994), Economic Journal (1996) and Islam (2003). For more recent work on evidence of and driving forces behind convergence patterns see, for example, Baumol et al. (1994), van Ark and Crafts (1996), Kumar and Rusell (2002), Miller and Upadhyah (2002) and Tondl (2001) among many others.
} 
Fallacy of regression towards the mean. ${ }^{4}$ In other words, $\beta$-convergence is a necessary but not a sufficient condition for $\sigma$-convergence. In this paper we will explore both patterns of $\sigma$ convergence and $\beta$-convergence. Moreover, we test whether convergence is conditional or unconditional and which are the factors explaining (cross-country differences in) labour- and energy productivity growth.

\section{DATA}

The analysis presented in this paper is based on a newly constructed database that merges energy data from the Energy Balances as they are published by the International Energy Agency (IEA) and economic data from the International Sectoral Database (ISDB) and the Structural Analysis Database (STAN), both published by the OECD. The main idea behind the construction of this database is to establish a link between economic and energy data at a detailed sectoral level. This results in the sector classification as described in Table 1.

\section{< Insert Table 1 around here >}

The database covers the period 1970-1997 and includes the following countries: Australia (AUS), Belgium (BEL), Canada (CAN), Denmark (DNK), Finland (FIN), France (FRA), West-Germany (WGR), Italy (ITA), Japan (JPN), the Netherlands (NLD), Norway (NOR), Sweden (SWE), United Kingdom (GBR) and the United States (USA).

We measure energy productivity by gross value added per unit of final energy consumption and labour productivity by gross value added per worker (in full time equivalents). Value added is the net economic output of a sector, measured by the price differential between the price of output and the cost of input and comprises compensation to employees, operating surplus, the consumption of fixed capital and the excess of indirect taxes over subsidies (OECD 1998). Following the IEA, energy use is defined as final energy consumption in kilo tonnes of oil equivalence (ktoe), ${ }^{5}$ with sectoral data excluding transformation losses. Total employment is measured in the full-time equivalent number of persons, including self-employed.

\footnotetext{
${ }^{4}$ See Bernard and Durlauf (1996) and Durlauf and Quah (1999) for further discussion of empirical methodological issues of convergence tests.

${ }^{5}$ Hence, we do not analyse explicitly the impact of changes in fuel mix on overall energy-efficiency improvements.
} 
Moreover, the database includes data on Investment, Energy Prices, Compensation of Employees, Export and Import - all at the sectoral level. The sector-specific energy prices are constructed by dividing sector-specific expenditures on energy over total sectoral energy consumption. The sector-specific expenditures are calculated as the product of the sectoral consumption of the four main energy carriers (Coal, Natural Gas, Electricity, Oil) - available from the Energy Balances - and the (annual) price of each energy carrier at the aggregate industrial sector - available from the IEA Energy Prices and Taxes series. In addition, some missing aggregate energy price data series have been constructed. ${ }^{6}$

All currency-denominated variables are in 1990 US\$ and have been converted by the OECD using 1990 purchasing power parities. In principle the theoretically most appropriate conversion factors for productivity comparisons at the sectoral level are to be based on a comparison of output prices by industry of origin, rather than on expenditure prices (see, for example, van Ark and Pilat 1993). Expenditure PPPs exclude the part of output that is exported, while they include imported goods produced elsewhere; they take account of differences in trade and transport margins and indirect taxes between countries, and they do not cover intermediate products. The main problem in using the production or industry-oforigin approach, however, is the limited availability of producer-price based PPPs, in particular for non-Manufacturing sectors (van Ark 1993). ${ }^{7}$ Moreover, we have no a priori reason to presume that the drawbacks of expenditure PPPs differ substantially across countries. Hence, we follow most studies including cross-country productivity comparisons using expenditure PPPs, which enables us to do a systematic cross-country convergence analysis of energy- and labour-productivity performance at a high level of sectoral detail. Obviously, the results presented in this paper should be interpreted with caution, bearing in mind the before mentioned issues. ${ }^{8}$

\footnotetext{
${ }^{6}$ Further details on the dataset, including descriptive statistics, are available upon request.

${ }^{7}$ This limited availability is due to some problems inherent to the industry-of-origin approach: producer prices (i.e., production values divided by output quantities) may not properly account for cross-country quality differences and imply aggregation problems for they are available only for a sample of goods (partly because of confidentiality problems), and because the production structure among countries tends to be less comparable than the consumption structure due to specialization tendencies in production according to comparative advantage (Pilat 1996).

${ }^{8}$ For a discussion of this issue in empirical analyses of convergence at the sectoral level see Sørensen (2001) and Bernard and Jones (2001).
} 


\section{4. $\sigma$-CONVERGENCE}

This section deals with the notion of convergence in terms of levels. Do cross-country differences in energy- and labour-productivity levels decrease over time? Are patterns of energy-productivity convergence similar to those of labour-productivity convergence? And to what extent do the results depend on the level of aggregation? To answer these questions we calculated for each sector the unweighted cross-country standard deviation $(\sigma)$ of the log of energy- and labour productivity, among the 14 OECD countries (insofar as data are available). ${ }^{9}$ Figure 1 presents the degree of variation in 'macroeconomic' energy- and labourproductivity levels, being the sum of aggregate Manufacturing, Transport, Services and Agriculture. ${ }^{10}$ The figure shows that cross-country differences in energy-productivity levels are substantially larger than cross-country differences of labour-productivity levels. Moreover, it can be seen that over time the standard deviation of the log of energyproductivity performance is increasing, indicating $\sigma$-divergence, while the opposite is true for cross-country labour-productivity performance, displaying a pattern of $\sigma$-convergence.

\section{$<$ Insert Figure 1 around here >}

As we noted in the introduction, a convergence analysis at aggregate levels may mask considerable variation in sectoral productivity developments (cf. Bernard and Jones, 1996a,b, Dollar and Wolff 1988, 1993). Therefore, we continue by examining the development of cross-country productivity differentials within different sectors.

In Figures $2 \mathrm{a}$ and $2 \mathrm{~b}$ we present the standard deviation of the $\log$ of, respectively, energy- and labour productivity for aggregate Manufacturing, Transport, Services and Agriculture. $^{11}$

\footnotetext{
${ }^{9}$ In the literature on convergence analysis, two measures for $\sigma$-convergence are used interchangeably: (1) the standard deviation of the log of per capita income or productivity $(y)$ and (2) the coefficient of variation which equals the standard deviation of per capita income or productivity divided by the sample average. Dalgaard and Vastrup (2001) show that these measures lead to different conclusions when applied to the Penn World Table caused by the fact that the measures assign different weights to individual countries' performance. We have therefore used both measures in our convergence analysis, finding both measures to yield an identical pattern of convergence, although with small differences in the size of cross-country variance. Details are available upon request. Here, we only present the result of the SD log-measure (1).

${ }^{10}$ Due to limited data availability the calculation of cross-country dispersion, as shown in Figure 1, excludes Canada, Japan, the Netherlands and Sweden.

${ }^{11}$ Due to limited data availability, the following countries are not included in the calculation of cross-country dispersion, shown in Figure 3. Manufacturing: Japan, the Netherlands; Agriculture: Japan, the Netherlands; Services: the Netherlands, Sweden; Transport: Canada, the Netherlands.
} 
From Figure 2a it can be seen that only Manufacturing resembles the macroeconomic pattern of $\sigma$-divergence for energy productivity. Transport, Agriculture, and in particular Services, display evidence of $\sigma$-convergence. Note that the level of cross-country variation is relatively high in Services, which is to a large extent due to the exceptional and so far unexplained energy-productivity performance of Finland and Italy. ${ }^{12}$ Figure $2 b$ shows that the macroeconomic pattern of $\sigma$-convergence for labour productivity is only evident in Services and to a lesser extent in the Agricultural sector. At the same time, variation in cross-country productivity differentials remains overall fairly constant within aggregate Manufacturing and Transport (although with fluctuations over time).

Comparing Figures $2 \mathrm{a}$ and $2 \mathrm{~b}$ shows again that in each sector the cross-country variation of energy productivity is substantially larger than of labour productivity. These results do not change when the United States is removed from the sample. Moreover, they accord well with the findings of Bernard and Jones (1996a), who by means of a conclusion suggest "that international flows, associated mostly with Manufacturing, may not be contributing substantially to convergence either through capital accumulation or technological transfer" (Bernard and Jones 1996a:1230). Our analysis suggests that this conclusion holds even stronger for manufacturing energy-productivity performance, where international flows cannot prevent an increase in cross-country differences of productivity levels.

This raises the question as to what the determinants of these cross-country productivity differences are. In our search for an answer we subsequently take three steps. First, we go one step further in the $\sigma$-convergence analysis than Bernard and Jones (1996a,b) by examining productivity convergence for a breakdown of aggregate Manufacturing in order to see to whether the energy-productivity divergence and the lack of labour-productivity convergence observed in aggregate Manufacturing is also found within the different Manufacturing sub-sectors. Second, we perform a $\beta$-convergence analysis to test whether a statistically significant negative relationship exists between the initial level and the growth rate of productivity performance, in order to gain a better insight in the mechanism behind the

\footnotetext{
${ }^{12}$ Excluding Finland and Italy from the sample for Services reduces the cross-country dispersion by about $40 \%$ while leaving the pattern of $\sigma$-convergence unchanged. Note that the Netherlands also exhibits an exceptional development of energy-productivity performance in Services, but has already been excluded form the sample used in Figure 3a.
} 
observed convergence patterns. Third, we will try to explain (persistent) differences in crosscountry productivity growth by examining the role of different country-specific variables in driving energy- and labour-productivity growth at the sectoral level. The remaining part of this section is devoted to a $\sigma$-convergence analysis for a breakdown of aggregate Manufacturing into 10 sub-sectors. The other issues are the subjects of section 4 .

In Figures $3 \mathrm{a}$ and $3 \mathrm{~b}$ we present the standard deviation of the log of, respectively, energy- and labour productivity for each of the 10 Manufacturing sub-sectors included in our dataset. ${ }^{13}$ Figure $3 \mathrm{a}$ reveals that the pattern of divergence in cross-country energyproductivity performance at the level of aggregate Manufacturing is to be found only in Iron and Steel and Non-Ferrous Metals. On the contrary, Food, Machinery, Non-metallic Minerals (until 1980) and Textiles all display evidence of (strong) $\sigma$-convergence. Cross-country productivity differences remain more or less constant in Non-Metallic Minerals (after 1980), Chemicals, Transport Equipment, Paper and Wood.

From Figure $3 b$ it can be seen that the lack of labour-productivity convergence in aggregate Manufacturing is the result of mixed convergence patterns in different manufacturing sectors. Chemicals, Iron and Steel, Non-ferrous Metals and Wood exhibit (strong) convergence, while Machinery shows the opposite pattern of divergence. The sectors Food, Non-Metallic Minerals, Textile, Paper and Transport Equipment display no clear evidence for either convergence or divergence, although the latter shows substantial fluctuations over time. Moreover, it is to be noted that in Chemicals, Iron and Steel, NonFerrous Metals and Non-Metallic Minerals convergence of labour-productivity performance is particularly strong during the first half of the 1980s.

$<$ Insert Figure $3 \mathrm{a}$ and $3 \mathrm{~b}$ around here $>$

In conclusion, we found cross-country variation of energy-productivity performance to be substantially higher than of labour-productivity performance at all levels of sectoral aggregation, and in particular in Services, Chemicals, Paper, Wood and at an ever increasing rate also in Iron and Steel and Non-Ferrous Metals. In Machinery, however, cross-country variation of energy- and labour-productivity differences has strongly converged, resulting in a

\footnotetext{
${ }^{13}$ Due to limited data availability, the following countries are excluded from the calculation of cross-country dispersion, shown in Figure 4. Food: Australia and Canada; Iron and steel: Japan; Machinery: Canada, Japan, the Netherlands; Transport Equipment: Canada; Non-Ferrous Metals: Denmark; Paper: Australia, Japan; Textile: Canada; Wood: Canada, France, Japan, United Kingdom, United States.
} 
relatively small - although seemingly persistent - difference in the degree of cross-country variance. Moreover, convergence patterns turned out to depend on the level of aggregation, with different sectors displaying varying behaviour: some show reduction in variation, some increasing variation and others neither a clear reduction or increase in cross-country differences over the whole period.

These results suggest that different mechanisms may be at work in the different sectors. For example, the observed patterns of divergence might be the result of increasing international specialization while the tendency to converge might be caused by technology spill-overs from 'leaders' to 'followers', allowing lagging countries to catch-up. Moreover, our results suggest that determinants of energy-productivity growth and labour-productivity growth might differ from each other, since we found no clear-cut (and sometimes even an opposite) relationship between cross-country convergence patterns in terms of energy productivity and labour productivity. Finally, even in those sectors showing evidence of convergence there remains substantial cross-country productivity differences, in particular in terms of energy productivity. This suggests that convergence does not pertain to a uniform steady state for all countries. In order to further examine this issue, we continue in the next section with a search for empirical regularities in the productivity improvements over our cross-section of countries by testing for sectoral patterns of $\beta$-convergence. As part of that analysis we will also try to explain (differences in) energy- and labour-productivity growth.

\section{5. $\beta$-CONVERGENCE}

This section deals with the notion of convergence in terms of growth rates. In this case energy- and labour-productivity convergence implies that energy- and labour-productivity growth rates tend to decline if countries reach their steady states. Obviously, it is not an easy task - if possible at all - to judge whether a country is in its steady state or not. It is possible, however, to analyse the correlation between growth rates and levels, assuming that a negative correlation between these two provides an indication for convergence, because it suggests that countries with relatively low initial energy- and labour-productivity levels catch-up to more advanced economies. The rationale behind this is that those countries lagging behind in terms of productivity levels can benefit from relatively high marginal factor productivity or from the experience and technologies developed by the countries operating at the forefront. In this section we adopt a panel-data framework to regress average energy- and labourproductivity growth rates on initial productivity levels, generating an estimate of the 
coefficient $\beta$, for each sector. A negative estimated coefficient $\beta$ indicates the existence of socalled $\beta$-convergence. We start in section 5.1 by testing for unconditional convergence, assuming that energy- and labour productivity converge towards a unique steady state for all countries included in the data set. In section 5.2 we relax this assumption and test for conditional convergence, assuming productivity levels to converge towards multiple steady states that are conditional on country-specific characteristics. Finally, as part of this analysis we try to identify the country-specific characteristics that determine (differences in) energyand labour-productivity growth across countries.

\subsection{Unconditional $\beta$-convergence}

We test for unconditional $\beta$-convergence by regressing for each sector the growth rate $(g)$ of, respectively, energy- and labour productivity (y), on its initial level (and a constant $\alpha$ ), generating an estimate of $\beta$, according to:

$$
g_{i t}=\log (y)_{i, t}-\log (y)_{i, t-1}=\alpha+\beta \ln (y)_{i, t-1}+\varepsilon_{i t}
$$

with $i$ and $t$ denoting, respectively, the cross-country and the time-series dimension, while $\varepsilon_{i t}$ is the standard error. Following Islam (1995) we use five-year time intervals in order to reduce the influence of business-cycle fluctuations and serial correlation of the error term. Hence, the growth rate $(g)$ in equation (1) is an average over a five-year period (if $t=1975$, for example, $t-1=1970$ ). The results are presented in Table 2 .

< Insert Table 2 around here >

From the table it can be seen that we obtain a statistically significant negative estimate of $\beta$ for energy-productivity growth in most sectors, except for Total (i.e., the macroeconomic level), Chemicals, Iron and Steel, Non-Ferrous Metals, Paper and Wood. In terms of labourproductivity growth we found $\beta$ to be statistically significant in all sectors, except for aggregate Manufacturing and Non-Ferrous Metals. ${ }^{14}$

\footnotetext{
${ }^{14}$ We also estimated equation (1) including a period-specific fixed effect $\eta_{t}$ according to $g_{i t}=\alpha+\beta \ln (y)_{i, t-1}+\eta_{t}$ $+\varepsilon_{i t}$. The regression results with these period dummies included do not substantially improve the estimates in most sectors, except for Non-Ferrous Metals and in terms of labour productivity also for Chemicals, Iron and Steel and Machinery. These findings suggest, that in spite of a few exceptions, in general there is not much evidence for substantial differences in growth rates between the time periods included. Details are available upon request.
} 
These results confirm the findings of Bernard and Jones (1996a) who also report lack of labour-productivity convergence in Manufacturing, weak evidence for convergence in Agriculture and strong evidence in Services. It is to be noted, however, that in most sectors that display evidence of convergence, estimates of $\beta$ are rather small, indicating that lagging countries catch-up only very slow. Using the estimated values of $\beta$, the rate at which the productivity level is converging to a uniform productivity level can be derived (e.g., Barro and Sala-i-Martin 1992, Mankiw et al. 1992, Islam 1995). Let $y^{*}$ be the steady state productivity level and $y(t)$ its actual value at any time $t$. Approximating around the steady state, the speed of convergence is given by

$$
\frac{d \log (y(t))}{d t}=\lambda\left[\log \left(y^{*}\right)-\log (y(t))\right]
$$

which implies that:

$$
\log (y(t))=\left(1-e^{-\lambda t}\right) \log \left(y^{*}\right)+e^{-\lambda t} \log (y(0))
$$

where $(y(0))$ is energy- or labour productivity level at some initial date. Subtracting log $(y(0))$ from both sides yields

$$
\log (y(t))-\log (y(0))=\left(1-e^{-\lambda t}\right)\left[\log \left(y^{*}\right)-\log (y(0))\right]
$$

in which $-\left(1-e^{-\lambda t}\right)=\beta$. Hence, the speed of convergence, $\lambda$, is given by $\lambda=-[1 / T \log (\beta+1)]$ with $T$ denoting the time interval under consideration. ${ }^{15}$ The values of the implied $\lambda$ are shown in Table 2. They confirm the finding of a slow rate of convergence: the time $t$ needed for energy productivity to move halfway its initial level $(y(0))$ and the steady state $y^{*}$ varies from 8 years (Textiles) to 225 years (Non-Ferrous metals); the half life for labour productivity lies in between 16 years (Wood) and 87 years (Manufacturing). ${ }^{16}$

As previously noted, $\beta$-convergence is a necessary but not a sufficient condition for $\sigma$ convergence. Our findings confirm that those sectors showing evidence of $\sigma$-convergence (see section 4) also display evidence of $\beta$-convergence: a decreasing cross-country variation of productivity levels implies by definition that countries with relatively low initial energyand labour-productivity levels grow relatively fast. However, the opposite is not necessarily true, as is illustrated for labour productivity by the sectors Machinery, Non-Metallic Minerals and Textiles: they pass the test for $\beta$-convergence without showing evidence of $\sigma$ convergence (see Figure 3b).

\footnotetext{
${ }^{15}$ Since we use five-year time intervals, $T=5$ in our analysis. Note that in Islam $(1995) \lambda=-[(1 / T) \ln (\beta)]$ due to the fact that he takes $\ln (y)_{i t}$ instead of $\left[\ln (y)_{i t}-\ln (y)_{i t-1}\right]$ as dependent variable.

${ }^{16}$ The half life $(H)$ is derived from $e^{-\lambda H}=0.5 \Leftrightarrow H=\ln (2) / \lambda$
} 
Finally, it is to be noted that the ability of the simple regression equation (1) to explain cross-country productivity growth rates is rather small in most sectors. This is not surprising since the specification of equation (1) implicitly builds upon the assumption that energy- and labour-productivity levels converge towards a uniform steady state. However, economies differ and so do (most likely) their steady states. Contrary to a framework of single cross-country regressions, a panel data framework is capable of allowing for crosscountry differences in steady states in the form of unobservable individual 'country-effects' (Islam 1995). These country-effects might include all sorts of country-specific tangible and intangible factors that affect productivity growth and which have not been included in equation (1) or, to state it differently, have been subsumed in its error term. Therefore, in the next section we test for $\beta$-convergence allowing for these 'country-effects'.

\subsection{Conditional $\beta$-convergence}

We test for conditional $\beta$-convergence by including (unspecified) individual country-effects in equation (1), assuming that productivity levels converge to country-specific steady states. Hence, we reformulate equation (1) into a panel-data model with individual country effects, according to:

$$
g_{i t}=\beta \ln (y)_{i, t-1}+\mu_{i}+\varepsilon_{i t}
$$

with $\mu_{i}$ representing unspecified country-specific (fixed) effects. In Table 3 we present - for each sector - the estimated coefficient $\beta$ obtained from equation (5).

< Insert Table 3 around here >

The table shows that allowing for individual country-effects substantially improves the explanatory power of the regression equations for both energy- and labour productivity. Moreover, in terms of energy productivity, equation (5) yields significantly negative estimates of $\beta$ in all sectors, including now also Total (i.e., the macroeconomic level), Chemicals, Iron and Steel, Non-Ferrous Metals and Machinery. Also in terms of labour productivity the estimates of $\beta$ are higher in several sectors such as, for example, Services and Food. The evidence on conditional labour-productivity convergence is, however, less clear-cut than it is for energy-productivity convergence: in some sectors such as, for example, 
Iron and Steel and Machinery, allowing for individual country-effects in explaining labourproductivity growth yields statistically less significant or even insignificant estimates of $\beta$.

This result suggests that in terms of labour productivity the variation in explanatory variables over time is relatively small as compared to cross-country differences, since correcting for the latter by means of including country-specific intercepts results in weaker evidence of a negative relationship between the initial labour productivity level and its growth over time. Nevertheless, the regression results suggest that both energy- and labourproductivity convergence depend to a large extent on individual country-effects, indicating energy- and labour productivity to be conditional rather than absolute in virtually all sectors. The latter is illustrated by the fact that the speed of conditional convergence is substantially higher than of unconditional convergence: for energy productivity the half life, as it follows from the implied $\lambda$, now lies between 1 year (Transport Equipment) and 14 years (Total) and for labour productivity it has been reduced to a period in between 47 years (Transport Equipment) and 77 years (Non-Ferrous Metals).

Of course, this brings back the question as to which are the country-specific variables driving energy- and labour-productivity growth and, hence, determining the country-specific steady states? Recall from the introduction that several mechanisms may be at work, causing 'followers' to grow faster than 'leaders': advanced economies may suffer from diminishing returns, lagging countries may benefit from knowledge spill-overs, production processes may convergence due to increasing competition, etcetera.

In order to explain (persistent) differences in cross-country energy- and labourproductivity growth we replace in equation (5) the unspecified country-effects $\mu_{i}$ by a number of country-specific explanatory variables $x_{i}^{j}$, according to:

$$
g_{i t}=\alpha+\beta \ln (y)_{i, t-1}+\sum_{j=1}^{5} \gamma_{j} x_{i t}^{j}+\varepsilon_{i t}
$$

The specified explanatory variables are defined at the sectoral level and include:

$$
\begin{array}{lll}
\text { Energy prices: } & x_{i t}^{1 a}=\frac{\left(p_{E, t}+p_{E, t-1}+p_{E, t-2}\right)}{3} \\
\text { Wages: } & x_{i t}^{1 b}=\frac{\left(w_{t}+w_{t-1}+w_{t-2}\right)}{3} \\
\text { Investment share: } & x_{i t}^{2}=\frac{I}{Y} \\
\text { Openness: } & x_{i t}^{3}=\frac{X G S+M G S}{Y}
\end{array}
$$


Balassa index: $\quad x_{i t}^{4}=\frac{X G S_{i} / \sum_{i=1}^{14} X G S_{i}}{\sum_{s=1}^{10} X G S_{i, s} / \sum_{i=1}^{14} \sum_{s=1}^{10} X G S_{i, s}}$

Economies of scale: $\quad x_{i t}^{5}=\frac{Y}{\sum_{s=1}^{13} Y}$

where sectoral indices are omitted for reasons of expositional clarity and with energy prices $\left(x_{i t}^{1 a}\right)$ or wages $\left(x_{i t}^{1 b}\right)$ included, respectively, in case of explaining energy-productivity growth or labour-productivity growth. We expect energy prices and wages to be positively correlated with, respectively, energy- and labour-productivity growth. We took a three-year moving average for the energy price and wages to avoid capturing the effect of short-term price fluctuations, assuming that investments in energy- and labour-augmenting technologies do respond to a structural trend in energy price/wage developments rather than to short term fluctuations. By including the investment share as an explanatory variable we test for the socalled embodiment hypothesis or a vintage effect, assuming that higher investment will contribute to increasing energy- and labour-productivity growth via technological change embodied in new capital goods (see, for example, Howarth et al. 1991 and Mulder et al. 2003). We expect openness to have a positive impact on productivity growth, since an open sector faces relatively strong competition as well as exchange of knowledge, which we both assume to have a stimulating effect on productivity growth. The Balassa index is an indictor measuring relative specialization patterns. We expect that if a country specializes in a particular sector, that that sector will be technologically relatively advanced, and hence we expect a positive effect on productivity. Finally, including an indicator for the relative size of a sector within a country captures the potential effect of economies of scale on productivity growth, assuming that a large sector is able to invest relatively much in R\&D and in new capital goods and, hence, might be a technological leader displaying relatively high productivity growth rates.

The results of regressing average energy-productivity growth rates on initial energy productivity levels and these additional explanatory variables, according to equation 6 , are presented in Table $4 .^{17}$

\footnotetext{
${ }^{17} \mathrm{We}$ also controlled for different specifications of energy prices (current prices, 5-year moving average, and $\log 3$-year and $\log 5$-year moving average), investment share $\left((I / Y)_{t-1},(I / K),(I / K)_{t-1}\right.$ and $\left.\ln (I / K)_{t-1}\right)$, as well as an interaction term of investment share and log initial energy productivity $\left(\ln (Y / E)_{0} *(I / Y)\right)$. All these specifications did not substantially alter the estimates. Details are available upon request.
} 
$<$ Insert Table 4 around here >

It can be seen that the regression analysis generates significantly negative estimates of $\beta$ in Agriculture, Transport, Iron and Steel, Machinery, Non-Metallic Minerals, Paper and Textiles. Compared to Table 3 this means that in 6 sectors the estimate of $\beta$ is no longer statistically significant once we include the previously mentioned specified explanatory variables. The effect of investment share, openness, specialization, and economies of scale on energy-productivity growth is mixed and their impact is statistically insignificant in virtually all sectors. An exception is the energy-price effect, which has in all sectors the expected (positive) sign, while the positive impact of energy prices on energy-productivity growth is statistically significant in Chemicals, Iron and Steel and Paper, which makes sense since these are energy intensive sectors. Finally, the speed of convergence has slowed down with the half life increased to a minimum of 5 years (Wood) and a maximum of 41 years (Chemicals).

In Table 5 we present the results of regressing average labour-productivity growth rates on initial labour-productivity levels and the five additional explanatory variables, according to equation (6).

$<$ Insert Table 5 around here >

Table 5 shows statistically significantly negative estimates of $\beta$ for Agriculture, Food and Textiles only. Similar to energy-productivity growth, the effect of the investment share, openness, specialization, and economies of scale on labour-productivity growth is mixed while their impact is statistically insignificant in virtually all sectors (or it is statistically significant with an unexpected sign such as, for example, in case of the 'vintage effect' in Agriculture, Iron and Steel, Transport Equipment and Wood, and economies of scale in Services). Finally, the speed of convergence has slowed down with the half life increasing to in between 12 years (Textiles) and 95 years (Machinery), while for Services the estimate yields a positive $\beta$, implying divergence.

In sum, while there is strong evidence of conditional convergence in terms of both energy- and labour-productivity growth (see Table 3), we found energy prices and in particular wages, investment share, openness, specialization and economies of scale to play 
only a limited role in explaining energy- and labour-productivity growth and, hence, in determining cross-country productivity differentials. The results shown in Tables 4 and 5 might, however, suffer from an omitted variable bias if the included explanatory variables are correlated with the unspecified country-effects $\mu_{i}$, which are excluded from equation (6). Hence, to correct for this potential bias, we add the unspecified individual country-effects to equation (6), according to

$$
g_{i t}=\alpha+\beta \ln (y)_{i, t-1}+\sum_{j=1}^{5} \gamma_{j} x_{i t}^{j}+\mu_{i}+\varepsilon_{i t}
$$

The results of this regression model for energy-productivity growth are presented in Table 6 .

\section{< Insert Table 6 around here >}

It can be seen that adding the unspecified country effects again affects the estimates substantially. The estimation results in Table 6 show that except for Food, Non-Ferrous Metals and Wood all sectors yield a statistically significant estimate of $\beta$, with regression equation (7) displaying a much better goodness of fit in most sectors than equation (6) (see Table 4). Except for Food and Non-Ferrous Metals, the speed of convergence has increased considerably as compared to Table 4 with the half-life to be between 1 and 5 years in all other sectors. The statistically significant energy-price effect is robust in Iron and Steel and in Paper, while in Chemicals the null hypothesis of no effect is only just rejected at the $10 \%$ level. In addition, energy prices also seem to have a statistically significant positive effect on energy-productivity growth in Services and Textiles. The impact of the other explanatory variables on energy-productivity growth remains mixed, with economies of scale having the largest statically significant effect on energy productivity growth, being positive in Services, Chemicals and Transport Equipment, while negative in Textiles. We found the vintage effect and openness to have a statistically significant positive effect in Transport Equipment only, while for specialization this is only the case in Iron and Steel.

In Table 7 we present the regression results of equation (7) for labour-productivity growth.

$<$ Insert Table 7 around here > 
It can be seen that in most sectors also labour-productivity growth is better explained if we account for country-specific fixed effects. Moreover, the speed of convergence increased in most sectors as compared to Table 5, with the half-life between 4 years (Transport) and 36 years (Agriculture), and with Machinery as the most important exception (with its half life increasing to 367 years). Table 7 shows that wages have a statistically significant positive effect on labour-productivity growth in Agriculture and Textiles, while this is negative in Transport Equipment. Moreover, similar to energy-productivity growth, the impact of the other explanatory variables on labour-productivity growth remains mixed, with economies of scale having again the largest statistically significant effect, being positive in Transport, NonFerrous Metals and Paper, while it is again negative in Textiles. We found openness to have a statistically significant positive effect in Paper only, while for specialization this is again only the case in Iron and Steel. Finally, the results do not give any support to the vintage effect, with the only statistically significant estimates displaying a negative sign.

\section{CONCLUSIONS}

This paper extends the existing empirical analyses of convergence patterns by providing a systematic comparison of energy- and labour-productivity convergence at a detailed sectoral level for 14 OECD countries, covering the period 1970-1997. A $\sigma$-convergence analysis revealed that the development of the cross-country variation in energy- and labourproductivity performance depends on the level of aggregation, with different patterns of productivity convergence and divergence across sectors. At the macroeconomic level we found evidence of energy-productivity divergence, driven by aggregate Manufacturing, as well as labour-productivity convergence, mainly driven by Services. The Manufacturing energy-productivity divergence turns out to be caused by the Iron and Steel and the NonFerrous Metals sectors. Moreover, despite a lack of evidence of labour-productivity convergence at the aggregate Manufacturing level, there is evidence of labour-productivity convergence in several Manufacturing sub-sectors, with Machinery as the most important exception in that it shows a clear pattern of divergence (in particular after 1985). A $\beta$ convergence analysis, using a panel-data approach, led tot the conclusion that in most sectors energy-productivity growth is relatively high in countries with relatively low initial productivity levels, while in several sectors this is also true for labour productivity. This result supports the hypothesis that relatively backward countries tend to catch-up to more advances economies, in particular in terms of energy productivity, possibly because they can 
benefit from the experience and technologies developed by the countries operating at the forefront.

However, in spite of the evidence of convergence, cross-country differences in energy- and labour-productivity performance seem to be persistent. Our $\beta$-convergence analysis has shown convergence to be conditional on cross-country differences in steady-state characteristics, rather than to be unconditional with productivity levels converging to a uniform steady state for all countries. This is in line with the results of our $\sigma$-convergence, which indicated that cross-country differences in productivity levels remain to exist, even in those sectors that display a convergence pattern. Moreover, we found that the speed of energy-productivity convergence is in general higher than the speed of labour-productivity convergence, in particular if we account for (unspecified) country-specific characteristics. Nevertheless, at the same time cross-country differences in energy-productivity levels were found to be still substantially larger than cross-country differences in labour-productivity levels at all levels of sectoral aggregation.

In our search for the country- and sector-specific fundamentals determining these (differences in) energy- and labour productivity developments, we found energy prices to stimulate energy-productivity growth in the energy-intensive sectors while we did not find much evidence of a positive relationship between wages and labour-productivity growth. Moreover, our data show the cross-country differences in wages to be considerably larger than cross-country differences in final energy prices (measured by the standard deviation of the $\log$ of each variable). Hence, they are not likely to explain the persistent relatively high cross-country differences in energy-productivity levels as compared to labour-productivity levels. In addition, we found economies of scale to contribute to energy- and labourproductivity growth in several sectors, while investment share, openness and specialization play only a very limited role in explaining (cross-country) differences in energy- and labourproductivity growth. Hence, there is a need for additional research to further explain sectoral trends in energy- and labour-productivity growth across countries.

A possible explanation for the relatively high variation in energy-productivity levels across countries might be that cross-country differences in environmental awareness (influenced by social pressure) or stringency of environmental policies cause energyefficiency improvements to be a matter of urgency at different degrees in different countries. Another reason might be a lack of international diffusion of energy-saving technologies as compared to technologies enhancing labour productivity. This can be caused by the fact that, 
in contrast with labour costs, in most sectors energy costs form only a small part of total production costs and, hence, firms do not have the incentive to search for best-practice technologies at the international market, as opposed to labour-augmenting technologies.

In any case, since productivity growth is primarily driven by technological change, our results suggest that patterns of international technology flows do exist, while at the same time they seem to be limited and at least to some extent sector-specific. There is some reason to believe that technology diffusion and knowledge spillovers are local rather than global (cf. Keller, 2002). This suggests the need for specific attention to be paid to the spatial dimension of technology diffusion in driving energy- and labour-productivity growth in different countries.

\section{References}

Abramovitz, M. (1986), 'Catching Up, Forging Ahead, and Falling Behind', Journal of Economic History, 47, pp. 385-406.

Ark, B. van (1993), International Comparisons of Output and Productivity, Monograph Series nr.1, Groningen, Growth and Development Centre.

Ark, B. van and D. Pilat (1993), 'Productivity Level in Germany, Japan, and the United States: Differences and Causes', Brookings Papers on Economic Activity. Microeconomics, 2, pp. 1-46.

Ark, B. van and N. Crafts (eds) (1996), Quantitative Aspects of Post-War European Growth, Cambridge, Cambridge University Press.

Barro, R.J. (1991), 'Economic Growth in a Cross-Section of Countries', Quarterly Journal of Economics, 106, pp. 407-443.

Barro, R.J. and X. Sala-i-Martin (1992), 'Convergence', Journal of Political Economy, 100, pp. 223-251.

Barro, R.J. and X. Sala-i-Martin (1995), Economic Growth, New York, McGraw Hill.

Baumol, W.J. (1986), 'Productivity Growth, Convergence and Welfare: What the Long-Run Data Show', American Economic Review, 76, pp. 1072-1085.

Baumol, W.J., R.R. Nelson and E.N. Wolff (1994), Convergence and Productivity; CrossNational Studies and Historical Evidence, Oxford, Oxford University Press.

Bernard, A.B. and C.I. Jones (1996a), 'Comparing Apples to Oranges: Productivity Convergence and Measurement across Industries and Countries', American Economic Review, 86, pp. 1216-1238.

Bernard, A.B. and C.I. Jones (1996b), 'Productivity Across Industries and Countries: Time Series Theory and Evidence', Review of Economics and Statistics, 78, pp. 135-146.

Bernard, A.B. and C.I. Jones (2001), 'Comparing Apples to Oranges: Productivity Convergence and Measurement Across Industries and Countries: Reply', American Economic Review, 91, pp. 1168-1169.

Bernard, A.B. and S.N. Durlauf (1996), 'Interpreting Tests of the Convergence Hypothesis', Journal of Econometrics, 71, pp. 161-173. 
Broadberry, S.N. (1996), 'Convergence: What the Historical Record Shows', in B. van Ark and N. Crafts (eds), Quantitative Aspects of Post-War European Growth, Cambridge, Cambridge University Press, pp. 327-346.

Chatterji, M. (1992), 'Convergence Clubs and Endogenous Growth', Oxford Review of Economic Policy, 8, pp. 57-69.

Chatterji, M., B. Gilmore, K. Strunk and J. Vanasin (1993), 'Political Economy, Growth and Convergence in Less-Developed Countries', World Development, 21, pp. 2029-2038.

Dalgaard, C.-J. and J. Vastrup (2001), 'On the Measurement of $\sigma$-Convergence', Economics Letters, 70, pp. 283-287.

DeLong, J.B. (1988), 'Productivity Growth, Convergence and Welfare: Comment', American Economic Review, 78, pp. 1138-1154.

Dollar, D. and E.N. Wolff (1988), 'Convergence of Industry Labour Productivity among Advanced Economies, 1963-1982', Review of Economics and Statistics, 70, pp. 549-558.

Dollar, D. and E.N. Wolff (1993), Competitiveness, Convergence, and International Specialization, Cambridge MA, MIT Press.

Durlauf, S.N. and P.A. Johnson (1992), Local versus Global Convergence Across National Economies, NBER Working Paper nr. 3996, Cambridge, MA.

Durlauf, S.N. and D. Quah (1999), 'New Empirics of Economic Growth', in: J.B. Taylor and M. Woodford (eds), Handbook of Macroeconomis, Volume 1, Amsterdam, North Holland Elsevier Science, pp. 235-308.

Economic Journal (1996), 'Controversy on the Convergence and Divergence of Growth Rates', Special Issue Economic Journal, 106, pp. 1016-1069.

Fagerberg, J. (1994), ‘Technology and International Differences in Growth Rates', Journal of Economic Literature, 32, pp. 1147-1175.

Gerschenkron, A. (1952), 'Economic Backwardness in Historical Perspective', in: B. Hoselitz (ed.), The Progress of Underdeveloped Areas, Chicago, University of Chicago Press, pp. 5-30.

Grossman, G.M. and E. Helpman (1991), Innovation and Growth in the Global Economy, Cambridge MA, MIT Press.

Howarth, R.B., L. Schipper, P.A. Duerr and S. Strøm (1991), 'Manufacturing Energy Use in 8 OECD Countries', Energy Economics, 13, pp. 135-42.

Islam, N. (1995), 'Growth Empirics: A Panel Data Approach', Quarterly Journal of Economics, 4, pp. 1127-1170.

Islam, N. (2003), 'What Have We Learnt from the Convergence Debate?', Journal of Economic Surveys, 17, pp. 309-362.

Jones, C.I. (1997), 'On the Evolution of World Income Distribution', Journal of Economic Perspectives, 11, pp. 19-36.

Keller, W. (2002), 'Geographic Localization of International Technology Diffusion', American Economic Review, 92, pp. 120-142.

Kumar, S. and R.R. Russell (2002), 'Technological Change, Technological Catch-Up, and Capital Deepening: Relative Contributions to Growth and Convergence', American Economic Review, 92, pp. 527-548.

Lucas, R.E. (1988), 'On the Mechanics of Economic Development', Journal of Monetary Economics, 22, pp. 3-42. 
Mankiw, N.G., D. Romer and D.N. Weil (1992), 'A Contribution to the Empirics of Economic Growth', Quarterly Journal of Economics, 107, pp. 407-437.

Miller, S.M. and M.P. Upadhyay (2002), 'Total Factor Productivity and the Convergence Hypothesis', Journal of Macroeconomics, 24, pp. 267-286.

Miketa, A. (2001), 'Analysis of Energy Intensity Developments in Manufacturing Sectors in Industrialized and Developing Countries', Energy Policy, 29, pp. 769-775.

Mulder, P. and H.L.F. de Groot (2003), International Comparisons of Sectoral Energy- and Labour- Productivity Performance. Stylised Facts and Decomposition of Trends, CPB Discussion paper nr. 22, The Hague.

Mulder, P., H.L.F. de Groot and M.W. Hofkes (2003), 'Explaining Slow Diffusion of Energy-Saving Technologies, A Vintage Model with Returns to Diversity and Learningby-Using', Resource and Energy Economics, 25, pp.105-126.

Quah, D. (1993), 'Galton's Fallacy and Test of the Convergence Hypothesis', Scandinavian Journal of Economics, 95, pp. 427-443.

Quah, D. (1997), 'Empirics for Growth and Distribution: Polarization, Stratification, and Convergence Clubs', Journal of Economic Growth, 2, pp. 27-59.

Romer, P.M. (1986), 'Increasing Returns and Long-Run Growth', Journal of Political Economy, 94, pp. 1002-1037.

Romer, P.M. (1990), 'Endogenous Technological Change', Journal of Political Economy, 98, pp. S71-S102.

Schipper, L. and S. Meyers (1992), Energy Efficiency and Human Activity: Past Trends and Future Prospects, Cambridge, Cambridge University Press.

Solow, R.M. (1956), 'A Contribution to the Theory of Economic Growth', Quarterly Journal of Economics, 70, pp. 65-94.

Sørensen, A. (2001), 'Comparing Apples to Oranges: Productivity Convergence and Measurement Across Industries and Countries: Comment', American Economic Review, 91, pp. 1160-1167.

Swan, T.W. (1956), 'Economic Growth and Capital Accumulation', Economic Record, 32, pp. 334-361.

Tondl, G. (2001), Convergence after Divergence? Regional Growth in Europe, Wien / New York, Springer.

Unander, F., S. Karbuz, L. Schipper, M. Khrushch and M. Ting (1999), 'Manufacturing Energy Use in OECD Countries: Decomposition of Long Term Trends', Energy Policy, 27, pp.769-778. 
Figure 1 Standard deviation of log energy- and labour productivity at the macroeconomic level (including aggregate Manufacturing, Transport, Services and Agriculture)

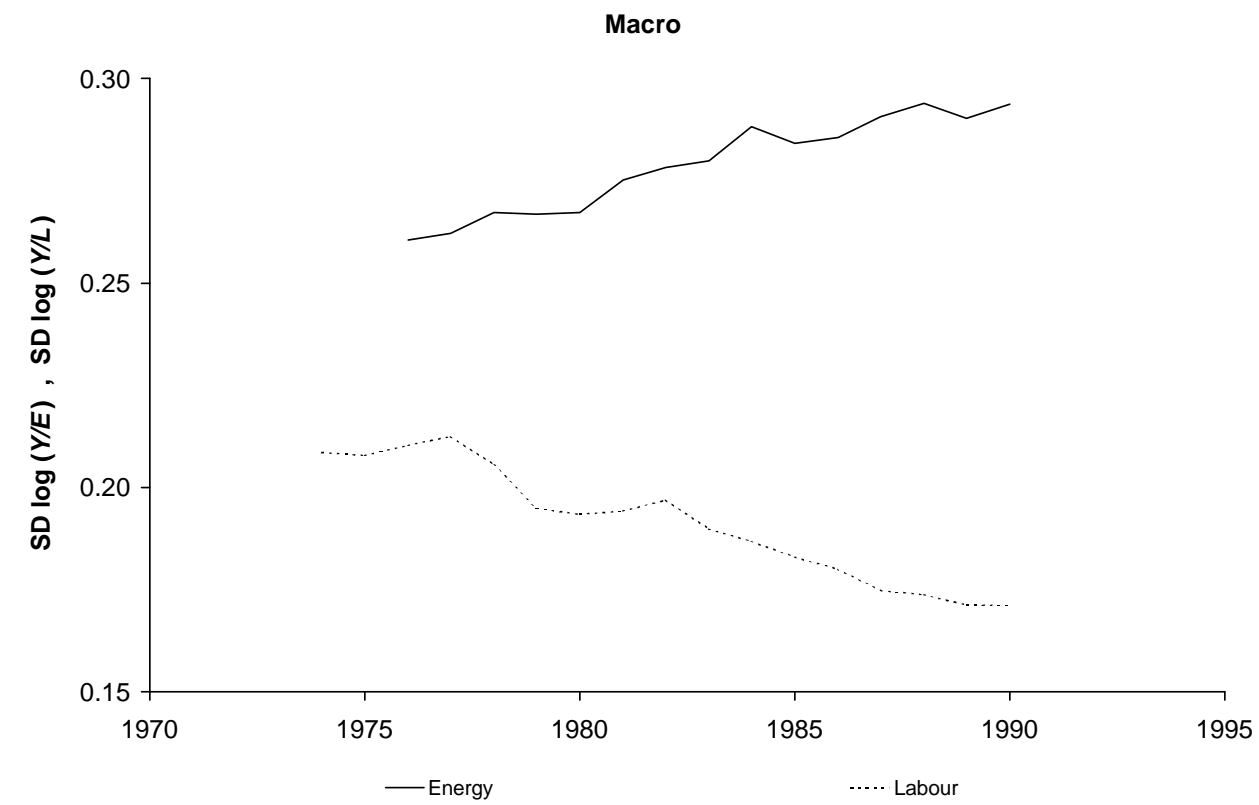

Figure 2a Standard deviation of log energy productivity in main sectors
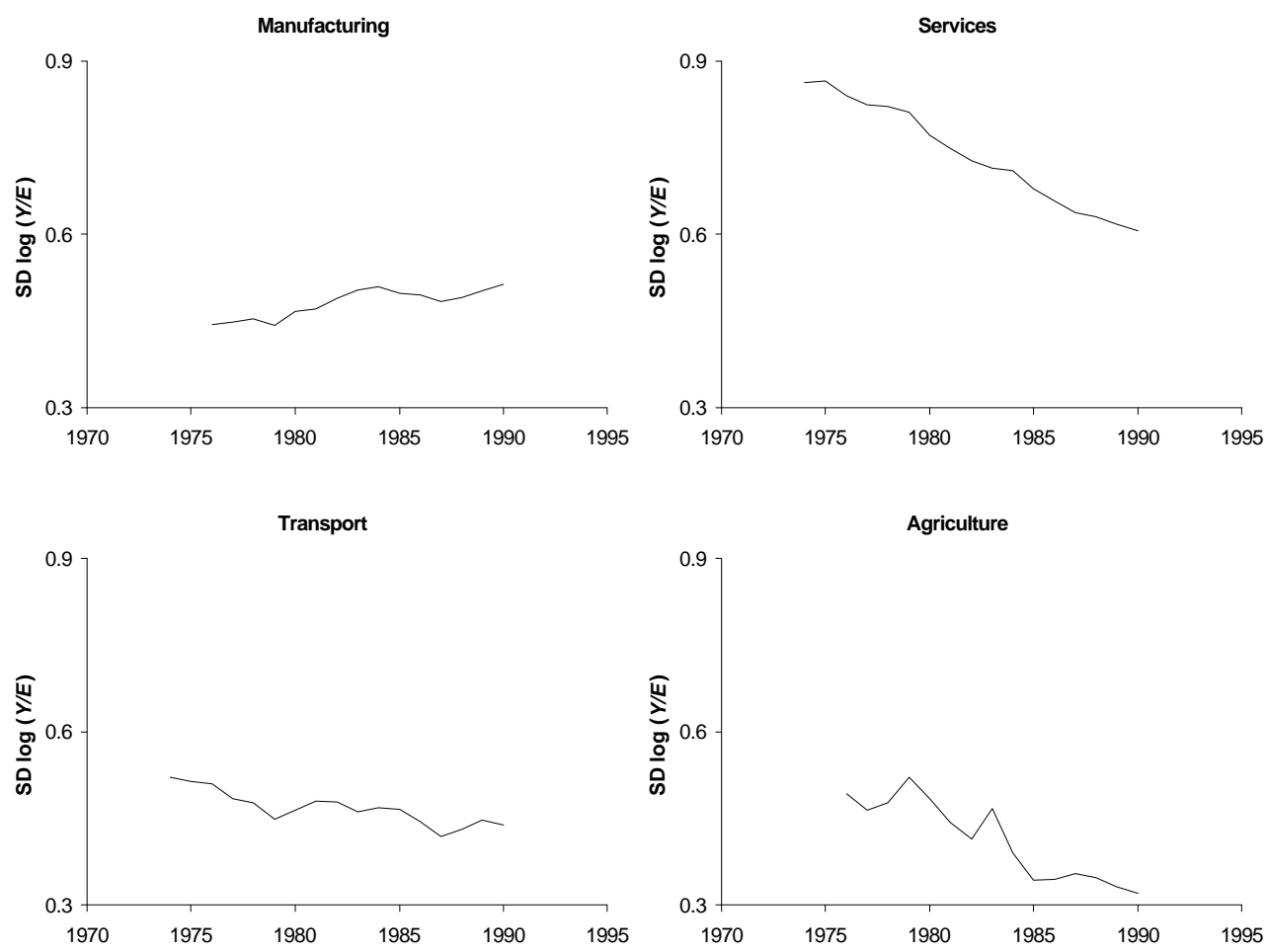
Figure 2b Standard deviation of log labour productivity in main sectors
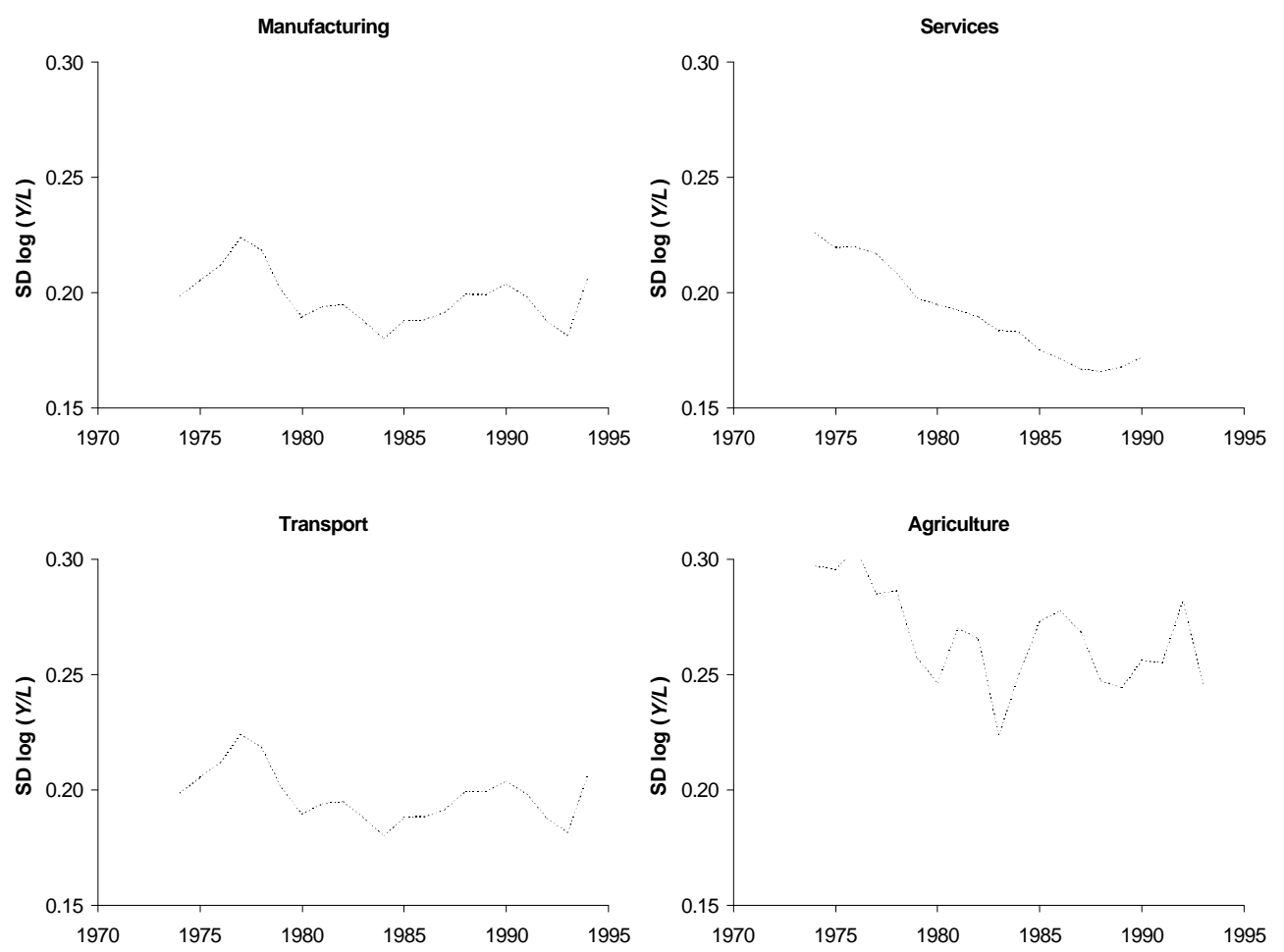
Figure 3a Standard deviation of log energy productivity in Manufacturing sectors
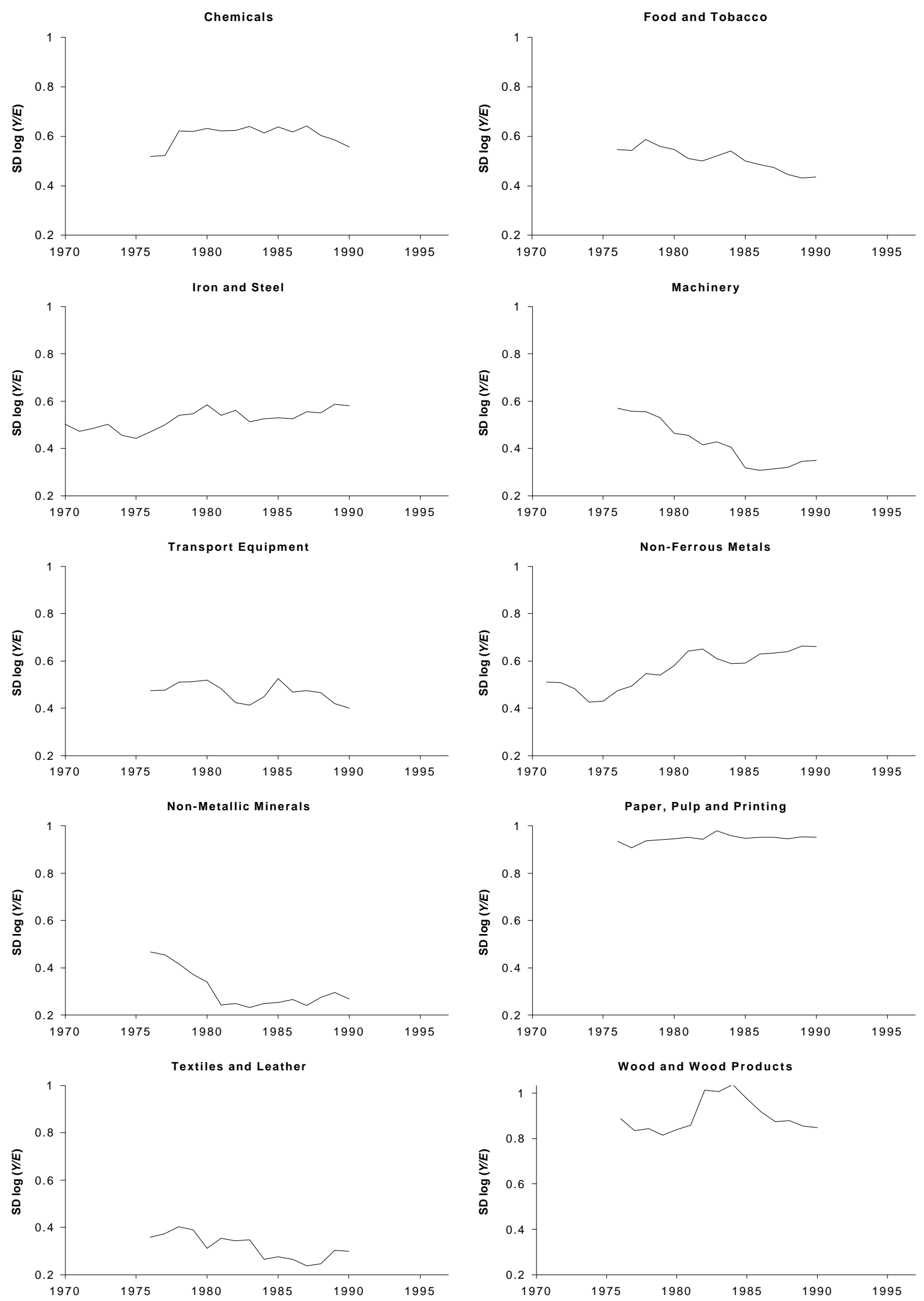
Figure 3b Standard deviation of log labour productivity in Manufacturing sectors
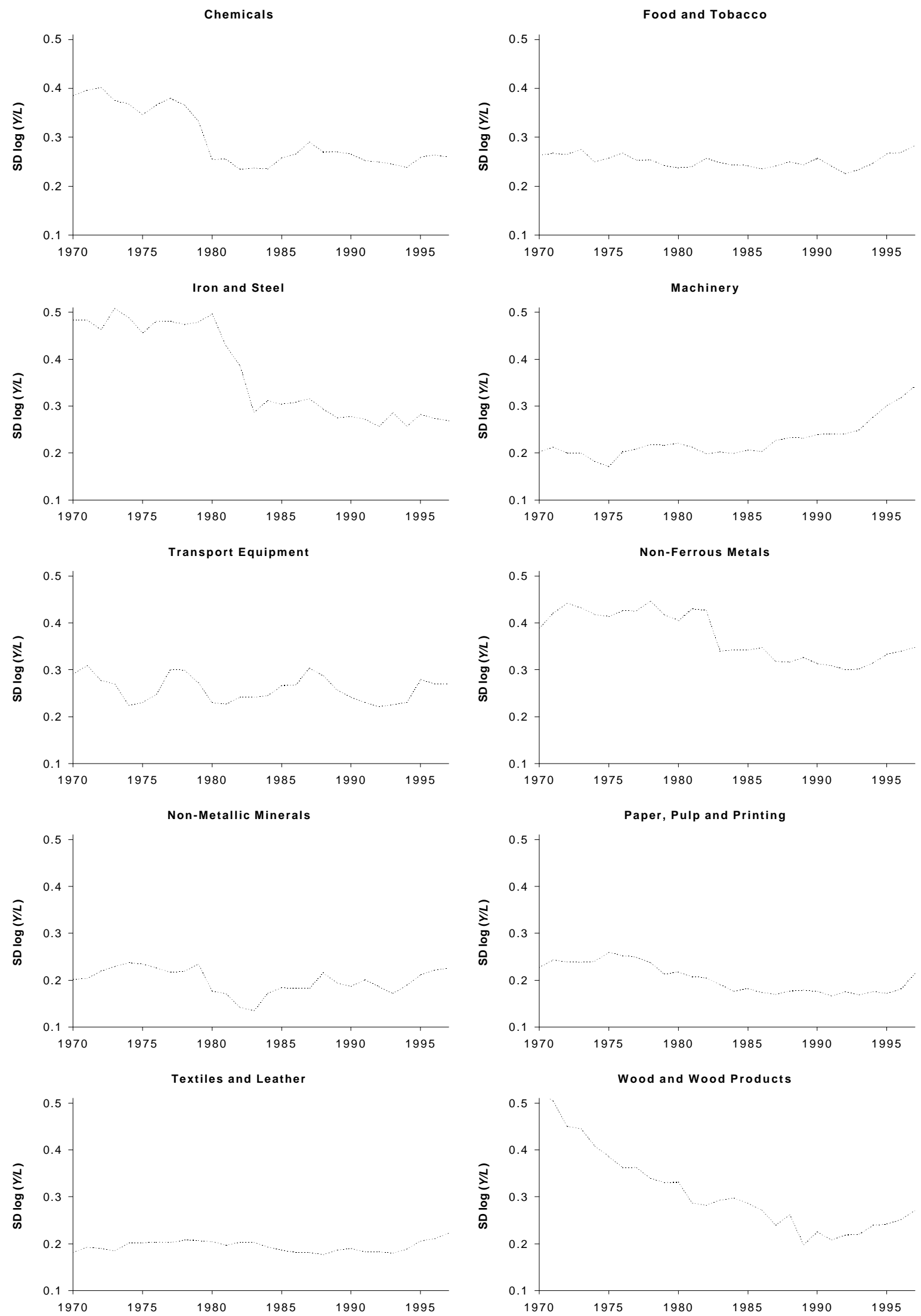
Table 1 Sector Classification

\begin{tabular}{|c|c|c|c|}
\hline \multicolumn{4}{|c|}{ ISIC Rev. 2 code } \\
\hline 1 & Food and Tobacco & FOD & 31 \\
\hline 2 & Textiles and Leather & TEX & 32 \\
\hline 3 & Wood and Wood Products & WOD & $331^{a}$ \\
\hline 4 & Paper, Pulp and Printing & PAP & 34 \\
\hline 5 & Chemicals & $\mathrm{CHE}$ & $351+352^{b}$ \\
\hline 6 & Non-Metallic Minerals & NMM & 36 \\
\hline 7 & Iron and Steel & IAS & 371 \\
\hline 8 & Non-Ferrous Metals & NFM & 372 \\
\hline 9 & Machinery & MAC & $381+382+383^{c}$ \\
\hline 10 & Transport Equipment & MTR & 384 \\
\hline 11 & Construction & CST & 50 \\
\hline 12 & Services & SRV & $61+62+63+72+81+82+83+90^{d}$ \\
\hline 13 & Transport & TAS & 71 \\
\hline 14 & Agriculture & AGR & 10 \\
\hline \multicolumn{4}{|c|}{${ }^{a}$ WOD excludes furniture since the sector WOD in the IEA Energy Balances excludes furniture } \\
\hline \multicolumn{4}{|c|}{${ }^{b} \mathrm{CHE}$ includes non-energetic energy consumption, i.e. using energy carriers as feedstock. } \\
\hline \multicolumn{4}{|c|}{$\begin{array}{l}{ }^{c} \text { MAC }=\text { Metal Products }(B M A, 381)+\text { Agricultural and Industrial Machinery }(\mathrm{MAI}, 382)+\text { Electrical Goods (MEL, 383); } \\
{ }^{d} \text { SRV }=\text { Wholesale and retail trade, restaurants and hotels }(\mathrm{RET})+\text { Communication }(\mathrm{COM})+\text { Finance, insurance, real } \\
\text { estate and business services }(\mathrm{FNI})+\text { Community, social and personal services }(\mathrm{SOC}) .\end{array}$} \\
\hline
\end{tabular}


Table 2 Unconditional $\beta$-convergence

\begin{tabular}{|c|c|c|c|c|c|c|}
\hline & \multicolumn{3}{|c|}{ Energy } & \multicolumn{3}{|c|}{ Labour } \\
\hline & $\beta_{\mathrm{E}}$ & $R^{2}$ & Implied $\lambda$ & $\beta_{\llcorner}$ & $R^{2}$ & Implied $\lambda$ \\
\hline \multirow[t]{2}{*}{ Total } & -0.0368 & 0.03 & 0.0075 & $-0.1138^{\star * *}$ & 0.30 & 0.0242 \\
\hline & $(0.0246)$ & & & $(0.0218)$ & & \\
\hline \multirow[t]{2}{*}{ Agriculture } & $-0.3227^{\star \star *}$ & 0.33 & 0.0779 & $-0.0575^{\star}$ & 0.03 & 0.0118 \\
\hline & $(0.0598)$ & & & $(0.0300)$ & & \\
\hline \multirow[t]{2}{*}{ Services } & $-0.1432^{\star \star *}$ & 0.26 & 0.0309 & $-0.1445^{\star \star *}$ & 0.44 & 0.0312 \\
\hline & $(0.0424)$ & & & $(0.0300)$ & & \\
\hline \multirow[t]{2}{*}{ Transport } & $-0.0827^{* *}$ & 0.12 & 0.0173 & $-0.1046^{* *}$ & 0.10 & 0.0221 \\
\hline & $(0.0312)$ & & & $(0.0465)$ & & \\
\hline \multirow[t]{2}{*}{ Manufacturing } & $-0.1524^{* * *}$ & 0.16 & 0.0331 & -0.0392 & 0.00 & 0.0080 \\
\hline & $(0.0459)$ & & & $(0.0324)$ & & \\
\hline \multirow[t]{2}{*}{ Chemicals } & -0.0190 & 0.01 & 0.0038 & $-0.1027^{\star \star *}$ & 0.12 & 0.0217 \\
\hline & $(0.0436)$ & & & $(0.0366)$ & & \\
\hline \multirow[t]{2}{*}{ Food and Tobacco } & $-0.0782^{* *}$ & 0.07 & 0.0163 & $-0.1058^{* *}$ & 0.12 & 0.0224 \\
\hline & $(0.0385)$ & & & $(0.0401)$ & & \\
\hline \multirow[t]{2}{*}{ Iron and Steel } & -0.0442 & 0.01 & 0.0090 & $-0.1060^{\star}$ & 0.05 & 0.0224 \\
\hline & $(0.0557)$ & & & $(0.0461)$ & & \\
\hline \multirow[t]{2}{*}{ Machinery } & $-0.1729^{\star \star \star}$ & 0.17 & 0.0380 & $-0.1263^{* *}$ & 0.12 & 0.0270 \\
\hline & $(0.0557)$ & & & $(0.0461)$ & & \\
\hline \multirow[t]{2}{*}{ Transport Equipment } & $-0.3082^{\star * \star}$ & 0.21 & 0.0737 & $-0.1480^{\star}$ & 0.07 & 0.0320 \\
\hline & $(0.0823)$ & & & $(0.0834)$ & & \\
\hline \multirow[t]{2}{*}{ Non-Ferrous Metals } & -0.0153 & 0.00 & 0.0031 & -0.0683 & 0.03 & 0.0141 \\
\hline & $(0.0617)$ & & & $(0.0494)$ & & \\
\hline \multirow[t]{2}{*}{ Non-Metallic Minerals } & $-0.3156^{\star \star *}$ & 0.24 & 0.0758 & $-0.1459^{\star \star *}$ & 0.12 & 0.0315 \\
\hline & $(0.0761)$ & & & $(0.0536)$ & & \\
\hline \multirow[t]{2}{*}{ Paper, Pulp and Printing } & -0.0435 & 0.03 & 0.0089 & $-0.0755^{\star \star}$ & 0.06 & 0.0157 \\
\hline & $(0.0355)$ & & & $(0.0376)$ & & \\
\hline \multirow[t]{2}{*}{ Textiles and Leather } & $-0.3497^{\star \star *}$ & 0.19 & 0.0861 & $-0.1577^{\star \star *}$ & 0.18 & 0.0343 \\
\hline & $(0.1020)$ & & & $(0.0433)$ & & \\
\hline \multirow[t]{2}{*}{ Wood and Wood Products } & -0.0236 & 0.01 & 0.0048 & $-0.1925^{\star \star \star}$ & 0.29 & 0.0428 \\
\hline & $(0.0349)$ & & & $(0.0381)$ & & \\
\hline
\end{tabular}


Table 3 Unspecified conditional $\beta$-convergence

\begin{tabular}{|c|c|c|c|c|c|c|}
\hline & \multicolumn{2}{|c|}{ Energy } & \multirow[b]{2}{*}{ Implied $\lambda$} & \multicolumn{2}{|c|}{ Labour } & \multirow[b]{2}{*}{ Implied $\lambda$} \\
\hline & $\beta_{\mathrm{E}}$ & $R^{2}$ & & $\beta_{\llcorner}$ & $R^{2}$ & \\
\hline Total & $\begin{array}{r}-0.2214^{* * *} \\
(0.0691)\end{array}$ & 0.19 & 0.0501 & $\begin{array}{r}-0.1068^{* * *} \\
(0.0262)\end{array}$ & 0.58 & 0.0226 \\
\hline Agriculture & $\begin{array}{r}-0.4797^{* * *} \\
(0.0888)\end{array}$ & 0.49 & 0.1307 & $\begin{array}{r}-0.0831^{*} \\
(0.0431)\end{array}$ & 0.22 & 0.0174 \\
\hline Services & $\begin{array}{r}-0.2181^{* *} \\
(0.1169)\end{array}$ & 0.44 & 0.0492 & $\begin{array}{r}-0.1783^{* * *} \\
(0.0422)\end{array}$ & 0.80 & 0.0393 \\
\hline Transport & $\begin{array}{r}-0.6301^{* * *} \\
(0.1593)\end{array}$ & 0.42 & 0.1989 & $\begin{array}{l}-0.1040 \\
(0.1115)\end{array}$ & 0.16 & 0.0220 \\
\hline Manufacturing & $\begin{array}{r}-0.6162^{\star \star *} \\
(0.0680)\end{array}$ & 0.67 & 0.1915 & $\begin{array}{r}-0.0553 \\
(0.0382)\end{array}$ & 0.16 & 0.0114 \\
\hline Chemicals & $\begin{array}{r}-0.2620^{\star * *} \\
(0.0836)\end{array}$ & 0.33 & 0.0608 & $\begin{array}{r}-0.0929^{*} \\
(0.0484)\end{array}$ & 0.29 & 0.0195 \\
\hline Food and Tobacco & $\begin{array}{r}-0.5180^{* * *} \\
(0.1292)\end{array}$ & 0.36 & 0.1460 & $\begin{array}{r}-0.1879^{* * *} \\
(0.0542)\end{array}$ & 0.49 & 0.0416 \\
\hline Iron and Steel & $\begin{array}{r}-0.3889^{* * *} \\
(0.1113)\end{array}$ & 0.32 & 0.0985 & $\begin{array}{r}-0.0642 \\
(0.1055)\end{array}$ & 0.11 & 0.0133 \\
\hline Machinery & $\begin{array}{r}-0.2305^{\star} \\
(0.1365)\end{array}$ & 0.31 & 0.0524 & $\begin{array}{l}-0.0549 \\
(0.0499)\end{array}$ & 0.45 & 0.0113 \\
\hline Transport Equipment & $\begin{array}{r}-0.9504^{* * *} \\
(0.1127)\end{array}$ & 0.68 & 0.6008 & $\begin{array}{r}-0.3104^{\star *} \\
(0.1253)\end{array}$ & 0.23 & 0.0743 \\
\hline Non-Ferrous Metals & $\begin{array}{r}-0.5924^{* * *} \\
(0.1426)\end{array}$ & 0.38 & 0.1795 & $\begin{array}{r}-0.0439 \\
(0.0932)\end{array}$ & 0.10 & 0.0090 \\
\hline Non-Metallic Minerals & $\begin{array}{r}-0.5087^{* * *} \\
(0.0980)\end{array}$ & 0.55 & 0.1421 & $\begin{array}{r}-0.2089^{* * *} \\
(0.0635)\end{array}$ & 0.39 & 0.0469 \\
\hline Paper, Pulp and Printing & $\begin{array}{r}-0.6513^{\star * *} \\
(0.1033)\end{array}$ & 0.60 & 0.2107 & $\begin{array}{l}-0.1053 \\
(0.0783)\end{array}$ & 0.24 & 0.0223 \\
\hline Textiles and Leather & $\begin{array}{r}-0.8612^{* * *} \\
(0.1285)\end{array}$ & 0.60 & 0.3949 & $\begin{array}{r}-0.2330^{* * *} \\
(0.0545)\end{array}$ & 0.33 & 0.0531 \\
\hline Wood and Wood Products & $\begin{array}{r}-1.0637^{* * *} \\
(0.1941\end{array}$ & 0.60 & -- & $\begin{array}{r}-0.2298^{* * *} \\
(0.0650)\end{array}$ & 0.47 & 0.0522 \\
\hline
\end{tabular}


Table 4 Specified conditional $\beta$-convergence energy productivity

\begin{tabular}{|c|c|c|c|c|c|c|c|c|c|}
\hline & $\beta$ & $\begin{array}{r}\text { Energy } \\
\text { Price }\end{array}$ & $\begin{array}{r}\text { Investment } \\
\text { share }\end{array}$ & Open & Balassa & $\begin{array}{c}\text { Value } \\
\text { added } \\
\text { share }\end{array}$ & $R^{2}$ & $F$-stat & Implied $\lambda$ \\
\hline Agriculture & $\begin{array}{r}-0.1995^{*} \\
(0.1136)\end{array}$ & $\begin{array}{r}0.0394 \\
(0.7225)\end{array}$ & $\begin{array}{r}-1.0158 \\
(0.8969)\end{array}$ & & & $\begin{array}{l}-2.2995 \\
(2.1086)\end{array}$ & 0.15 & 1.10 & 0.0445 \\
\hline Services & $\begin{array}{r}-0.2296 \\
(0.1791)\end{array}$ & $\begin{array}{l}-0.0147 \\
(0.5612)\end{array}$ & $\begin{array}{l}0.0714 \\
(0.918)\end{array}$ & & & $\begin{array}{r}0.3858 \\
(0.9388)\end{array}$ & 0.45 & 2.25 & 0.0522 \\
\hline Transport & $\begin{array}{r}-0.2350^{\star \star *} \\
(0.0655)\end{array}$ & $\begin{array}{r}0.1168 \\
(0.1439)\end{array}$ & $\begin{array}{l}0.7991^{* *} \\
(0.3266)\end{array}$ & & & $\begin{array}{l}4.1693^{* *} \\
(1.6905)\end{array}$ & 0.46 & 3.87 & 0.0536 \\
\hline Chemicals & $\begin{array}{r}-0.0820 \\
(0.0819)\end{array}$ & $\begin{array}{l}1.3526^{\star *} \\
(0.5008)\end{array}$ & $\begin{array}{r}0.9093 \\
(1.2271)\end{array}$ & $\begin{array}{l}-0.0427 \\
(0.0335)\end{array}$ & $\begin{array}{r}0.1631 \\
(0.1661)\end{array}$ & $\begin{array}{l}-4.8405 \\
(8.5819)\end{array}$ & 0.28 & 1.39 & 0.0171 \\
\hline Food & $\begin{array}{r}-0.1211 \\
(0.0745)\end{array}$ & $\begin{array}{r}0.2130 \\
(0.4951)\end{array}$ & $\begin{array}{l}-0.5277 \\
(0.9092)\end{array}$ & $\begin{array}{l}-0.0432 \\
(0.0363)\end{array}$ & $\begin{array}{r}0.0113 \\
(0.0308)\end{array}$ & $\begin{array}{l}5.5691 \\
(3.829)\end{array}$ & 0.35 & 1.79 & 0.0258 \\
\hline Iron and Steel & $\begin{array}{r}-0.3377^{\star *} \\
(0.1252)\end{array}$ & $\begin{array}{l}1.9263^{* *} \\
(0.7689)\end{array}$ & $\begin{array}{l}-0.8636 \\
(0.7094)\end{array}$ & $\begin{array}{l}-0.0251 \\
(0.0184)\end{array}$ & $\begin{array}{r}0.0068 \\
(0.1095)\end{array}$ & $\begin{array}{r}-9.5859 \\
(10.7085)\end{array}$ & 0.44 & 2.79 & 0.0824 \\
\hline Machinery & $\begin{array}{r}-0.2042^{* * *} \\
(0.0684)\end{array}$ & $\begin{array}{r}0.4170 \\
(0.4823)\end{array}$ & $\begin{array}{r}0.7337 \\
(1.7063)\end{array}$ & $\begin{array}{r}0.0131 \\
(0.0345)\end{array}$ & $\begin{array}{r}-0.1112 \\
(0.1997)\end{array}$ & $\begin{array}{r}2.3311 \\
(1.6439)\end{array}$ & 0.43 & 2.48 & 0.0457 \\
\hline Transport Equipment & $\begin{array}{l}-0.2855 \\
(0.1888)\end{array}$ & $\begin{array}{r}-0.1642 \\
(0.729)\end{array}$ & $\begin{array}{r}0.4689 \\
(1.6648)\end{array}$ & $\begin{array}{r}0.0011 \\
(0.0472)\end{array}$ & $\begin{array}{r}0.2225 \\
(0.2079)\end{array}$ & $\begin{array}{r}-8.1921 \\
(13.7238)\end{array}$ & 0.25 & 0.79 & 0.0672 \\
\hline Non-Ferrous Metals & $\begin{array}{l}-0.0844 \\
(0.2229)\end{array}$ & $\begin{array}{r}0.3943 \\
(0.5285)\end{array}$ & $\begin{array}{r}0.0573 \\
(0.2724)\end{array}$ & $\begin{array}{l}-0.0307 \\
(0.0208)\end{array}$ & $\begin{array}{l}-0.0943 \\
(0.1549)\end{array}$ & $\begin{array}{r}-0.4460 \\
(36.3853)\end{array}$ & 0.20 & 0.75 & 0.0176 \\
\hline Non-Metallic Minerals & $\begin{array}{r}-0.4561^{* * *} \\
(0.1611)\end{array}$ & $\begin{array}{r}1.8238 \\
(1.0916)\end{array}$ & $\begin{array}{r}0.0505 \\
(1.1821)\end{array}$ & $\begin{array}{l}-0.0336 \\
(0.1062)\end{array}$ & $\begin{array}{r}0.2064 \\
(0.2016)\end{array}$ & $\begin{array}{r}-36.2293^{*} \\
(20.1039)\end{array}$ & 0.32 & 1.63 & 0.1218 \\
\hline Paper & $\begin{array}{r}-0.1118^{*} \\
(0.0613)\end{array}$ & $\begin{array}{l}0.6632^{* *} \\
(0.3052)\end{array}$ & $\begin{array}{l}-0.8569 \\
(0.8666)\end{array}$ & $\begin{array}{l}-0.0740 \\
(0.0527)\end{array}$ & $\begin{array}{l}-0.0643 \\
(0.0723)\end{array}$ & $\begin{array}{r}7.5805 \\
(6.1778)\end{array}$ & 0.47 & 2.76 & 0.0237 \\
\hline Textiles & $\begin{array}{r}-0.3656^{*} \\
(0.2053)\end{array}$ & $\begin{array}{r}-0.4195 \\
(0.783)\end{array}$ & $\begin{array}{r}0.3092 \\
(3.1265)\end{array}$ & $\begin{array}{l}-0.0497 \\
(0.0368)\end{array}$ & $\begin{array}{r}0.2136 \\
(0.2621)\end{array}$ & $\begin{array}{l}-11.7071 \\
(19.7875)\end{array}$ & 0.29 & 1.29 & 0.0910 \\
\hline Wood & $\begin{array}{l}-0.4686 \\
(0.3351)\end{array}$ & $\begin{array}{r}-0.8418 \\
(0.5508)\end{array}$ & $\begin{array}{l}-2.7443 \\
(2.2403)\end{array}$ & $\begin{array}{r}-0.1293^{*} \\
(0.0699)\end{array}$ & $\begin{array}{r}0.0229 \\
(0.0667)\end{array}$ & $\begin{array}{r}-53.1902 \\
(34.2262)\end{array}$ & 0.51 & 1.23 & 0.1264 \\
\hline
\end{tabular}


Table 5 Specified conditional $\beta$-convergence labour productivity

\begin{tabular}{|c|c|c|c|c|c|c|c|c|c|}
\hline & $\beta$ & Wage & $\begin{array}{r}\text { Investment } \\
\text { share }\end{array}$ & Open & Balassa & $\begin{array}{c}\text { Value } \\
\text { added } \\
\text { share }\end{array}$ & $R^{2}$ & $F$-stat & Implied $\lambda$ \\
\hline Agriculture & $\begin{array}{r}-0.1050^{\star \star} \\
(0.0456)\end{array}$ & $\begin{array}{r}0.0315 \\
(0.4028)\end{array}$ & $\begin{array}{r}-0.6869^{* *} \\
(0.3014)\end{array}$ & & & $\begin{array}{r}0.2704 \\
(0.8205)\end{array}$ & 0.24 & 2.48 & 0.0222 \\
\hline Services & $\begin{array}{r}0.0450 \\
(0.0616)\end{array}$ & $\begin{array}{r}0.0032 \\
(0.0028)\end{array}$ & $\begin{array}{r}0.1665 \\
(0.1467)\end{array}$ & & & $\begin{array}{r}-0.6100^{* * *} \\
(0.2173)\end{array}$ & 0.70 & 8.07 & -0.0088 \\
\hline Transport & $\begin{array}{r}-0.1778 \\
(0.1123)\end{array}$ & $\begin{array}{r}0.0805 \\
(0.1180)\end{array}$ & $\begin{array}{r}0.1422 \\
(0.3348)\end{array}$ & & & $\begin{array}{r}0.9614 \\
(1.8576)\end{array}$ & 0.19 & 1.26 & 0.0392 \\
\hline Chemicals & $\begin{array}{r}-0.1037 \\
(0.076)\end{array}$ & $\begin{array}{r}0.1050 \\
(0.2568)\end{array}$ & $\begin{array}{l}-0.1674 \\
(0.3365)\end{array}$ & $\begin{array}{l}-0.0111 \\
(0.0196)\end{array}$ & $\begin{array}{r}0.0978 \\
(0.0951)\end{array}$ & $\begin{array}{l}-2.8729 \\
(4.5006)\end{array}$ & 0.20 & 1.21 & 0.0219 \\
\hline Food & $\begin{array}{r}-0.2054^{* *} \\
(0.0822)\end{array}$ & $\begin{array}{r}0.2028 \\
(0.1436)\end{array}$ & $\begin{array}{l}-0.3856 \\
(0.5348)\end{array}$ & $\begin{array}{r}0.0167 \\
(0.0258)\end{array}$ & $\begin{array}{l}-0.0003 \\
(0.0212)\end{array}$ & $\begin{array}{l}-0.8228 \\
(2.5040)\end{array}$ & 0.33 & 2.22 & 0.0460 \\
\hline Iron and Steel & $\begin{array}{r}-0.1224 \\
(0.0748)\end{array}$ & $\begin{array}{l}-0.2134 \\
(0.5454)\end{array}$ & $\begin{array}{r}-0.6313^{\star *} \\
(0.2447)\end{array}$ & $\begin{array}{r}0.0074 \\
(0.0113)\end{array}$ & $\begin{array}{r}0.0554 \\
(0.1089)\end{array}$ & $\begin{array}{l}-4.4848 \\
(7.5135)\end{array}$ & 0.34 & 2.44 & 0.0261 \\
\hline Machinery & $\begin{array}{l}-0.0360 \\
(0.1253)\end{array}$ & $\begin{array}{r}0.0227 \\
(0.1023)\end{array}$ & $\begin{array}{l}-2.9856 \\
(1.8858)\end{array}$ & $\begin{array}{r}0.0183 \\
(0.0328)\end{array}$ & $\begin{array}{l}-0.1914 \\
(0.2035)\end{array}$ & $\begin{array}{l}-0.3505 \\
(1.2179)\end{array}$ & -0.14 & 0.53 & 0.0073 \\
\hline Transport Equipment & $\begin{array}{r}0.3188 \\
(0.3182)\end{array}$ & $\begin{array}{r}-0.8364 \\
(0.6482)\end{array}$ & $\begin{array}{r}-1.3317^{*} \\
(0.7010)\end{array}$ & $\begin{array}{l}-0.0106 \\
(0.0188)\end{array}$ & $\begin{array}{r}0.5252 \\
(0.3654)\end{array}$ & $\begin{array}{r}-8.1424 \\
(6.8885)\end{array}$ & 0.51 & 1.20 & -0.0553 \\
\hline Non-Ferrous Metals & $\begin{array}{l}-0.0531 \\
(0.0672)\end{array}$ & $\begin{array}{l}-0.5926 \\
(1.2052)\end{array}$ & $\begin{array}{l}-0.0312 \\
(0.1540)\end{array}$ & $\begin{array}{r}0.0085 \\
(0.0114)\end{array}$ & $\begin{array}{l}-0.0279 \\
(0.0575)\end{array}$ & $\begin{array}{r}21.6064 \\
(25.3957)\end{array}$ & 0.10 & 0.52 & 0.0109 \\
\hline Non-Metallic Minerals & $\begin{array}{r}-0.1192 \\
(0.1140)\end{array}$ & $\begin{array}{r}0.0392 \\
(0.5893)\end{array}$ & $\begin{array}{l}-0.6816 \\
(0.5820)\end{array}$ & $\begin{array}{r}0.0169 \\
(0.0629)\end{array}$ & $\begin{array}{l}-0.0028 \\
(0.0968)\end{array}$ & $\begin{array}{r}5.3651 \\
(10.2905)\end{array}$ & 0.12 & 0.61 & 0.0254 \\
\hline Paper & $\begin{array}{l}-0.0946 \\
(0.1009)\end{array}$ & $\begin{array}{r}0.0711 \\
(0.1254)\end{array}$ & $\begin{array}{l}-0.7480 \\
(0.4340)\end{array}$ & $\begin{array}{r}0.0504 \\
(0.0378)\end{array}$ & $\begin{array}{r}0.0047 \\
(0.0208)\end{array}$ & $\begin{array}{r}3.1122 \\
(2.9214)\end{array}$ & 0.37 & 2.63 & 0.0199 \\
\hline Textiles & $\begin{array}{r}-0.2539^{* * *} \\
(0.0755)\end{array}$ & $\begin{array}{r}0.0173 \\
(0.2092)\end{array}$ & $\begin{array}{r}0.3843 \\
(1.1500)\end{array}$ & $\begin{array}{r}-0.0194 \\
(0.0158)\end{array}$ & $\begin{array}{r}-0.0088 \\
(0.078)\end{array}$ & $\begin{array}{r}-4.8024 \\
(6.2200)\end{array}$ & 0.46 & 3.88 & 0.0586 \\
\hline Wood & $\begin{array}{r}-0.1102 \\
(0.1214)\end{array}$ & $\begin{array}{l}-0.2230 \\
(0.7199)\end{array}$ & $\begin{array}{r}-0.8868^{* *} \\
(0.4077)\end{array}$ & $\begin{array}{l}-0.0175 \\
(0.0321)\end{array}$ & $\begin{array}{r}-0.0030 \\
(0.0155)\end{array}$ & $\begin{array}{r}8.9504 \\
(6.0659)\end{array}$ & 0.30 & 1.65 & 0.0234 \\
\hline
\end{tabular}


Table 6 Conditional $\beta$-convergence energy productivity, specified, fixed effects

\begin{tabular}{|c|c|c|c|c|c|c|c|c|c|}
\hline & $\beta$ & $\begin{array}{r}\text { Energy } \\
\text { Price }\end{array}$ & $\begin{array}{r}\text { Investment } \\
\text { share }\end{array}$ & Open & Balassa & $\begin{array}{r}\text { Value } \\
\text { added share }\end{array}$ & $R^{2}$ & $F$-stat & Implied $\lambda$ \\
\hline Agriculture & $\begin{array}{r}-0.8615^{* * *} \\
(0.1965)\end{array}$ & $\begin{array}{r}1.3546 \\
(1.1801)\end{array}$ & $\begin{array}{r}0.2182 \\
(1.1274)\end{array}$ & & & $\begin{array}{r}12.3662 \\
(7.6932)\end{array}$ & 0.64 & 9.54 & 0.3954 \\
\hline Services & $\begin{array}{r}-0.8039^{\star * *} \\
(0.238)\end{array}$ & $\begin{array}{l}1.1183^{*} \\
(0.6375\end{array}$ & $\begin{array}{r}-0.5308 \\
(0.7828)\end{array}$ & & & $\begin{array}{l}7.1791^{* *} \\
(3.2129)\end{array}$ & 0.81 & 9.88 & 0.3258 \\
\hline Transport & $\begin{array}{r}-0.5122^{*} \\
(0.2604)\end{array}$ & $\begin{array}{r}0.0540 \\
(0.1633)\end{array}$ & $\begin{array}{l}-0.0171 \\
(0.3651)\end{array}$ & & & $\begin{array}{r}16.8394 \\
(4.3809)\end{array}$ & 0.80 & 15.84 & 0.1436 \\
\hline Chemicals & $\begin{array}{r}-0.7638^{* * *} \\
(0.1475)\end{array}$ & $\begin{array}{r}0.7270 \\
(0.4416)\end{array}$ & $\begin{array}{r}1.7622 \\
(1.0992)\end{array}$ & $\begin{array}{r}0.0023 \\
(0.0323)\end{array}$ & $\begin{array}{l}-0.4818 \\
(0.3812)\end{array}$ & $\begin{array}{r}76.7954^{\star \star *} \\
(13.9899)\end{array}$ & 0.88 & 19.29 & 0.2886 \\
\hline Food & $\begin{array}{r}-0.0403 \\
(0.3799)\end{array}$ & $\begin{array}{r}1.0346 \\
(0.7692)\end{array}$ & $\begin{array}{r}-0.5494 \\
(1.0185)\end{array}$ & $\begin{array}{r}-0.2596^{\star *} \\
(0.1147)\end{array}$ & $\begin{array}{r}-0.5764 \\
(0.394)\end{array}$ & $\begin{array}{r}-0.7585 \\
(10.9498)\end{array}$ & 0.63 & 4.13 & 0.0082 \\
\hline Iron and Steel & $\begin{array}{r}-0.8670^{* * *} \\
(0.1679)\end{array}$ & $\begin{array}{r}3.8639^{\star * *} \\
(1.2861)\end{array}$ & $\begin{array}{r}-1.3162^{\star *} \\
(0.6329)\end{array}$ & $\begin{array}{l}0.0052 \\
(0.031)\end{array}$ & $\begin{array}{r}0.9330^{* * *} \\
(0.2287)\end{array}$ & $\begin{array}{r}-5.4317 \\
(18.3749)\end{array}$ & 0.85 & 14.58 & 0.4035 \\
\hline Machinery & $\begin{array}{r}-0.5964^{\star *} \\
(0.2732)\end{array}$ & $\begin{array}{r}-0.3718 \\
(1.1718)\end{array}$ & $\begin{array}{l}3.8541 \\
(3.208)\end{array}$ & $\begin{array}{r}0.1009 \\
(0.0971)\end{array}$ & $\begin{array}{r}0.6565 \\
(0.8200)\end{array}$ & $\begin{array}{r}3.7735 \\
(5.8699)\end{array}$ & 0.66 & 4.62 & 0.1815 \\
\hline Transport Equipment & $\begin{array}{r}-1.1444^{* * *} \\
(0.2930)\end{array}$ & $\begin{array}{r}-1.6712^{* * *} \\
(0.5916)\end{array}$ & $\begin{array}{l}3.4196^{* *} \\
(1.4195)\end{array}$ & $\begin{array}{r}0.2016^{\star * *} \\
(0.0718)\end{array}$ & $\begin{array}{r}0.2657 \\
(0.5175)\end{array}$ & $\begin{array}{l}57.3976 * \star \\
(26.7348)\end{array}$ & 0.84 & 8.30 & --- \\
\hline Non-Ferrous Metals & $\begin{array}{r}-0.0262 \\
(0.2872)\end{array}$ & $\begin{array}{r}0.5837 \\
(1.1114)\end{array}$ & $\begin{array}{l}0.0350 \\
(0.429)\end{array}$ & $\begin{array}{r}-0.0494 \\
(0.0552)\end{array}$ & $\begin{array}{r}0.0833 \\
(0.2178)\end{array}$ & $\begin{array}{l}132.9891 \\
(80.1969)\end{array}$ & 0.56 & 2.76 & 0.0053 \\
\hline Non-Metallic Minerals & $\begin{array}{r}-0.9527^{* * *} \\
(0.1758)\end{array}$ & $\begin{array}{l}0.2167 \\
(1.593)\end{array}$ & $\begin{array}{r}1.3573 \\
(1.2800)\end{array}$ & $\begin{array}{r}0.0321 \\
(0.1503)\end{array}$ & $\begin{array}{r}-0.1779 \\
(0.2079)\end{array}$ & $\begin{array}{l}-17.6544 \\
(32.8798)\end{array}$ & 0.80 & 10.53 & 0.6102 \\
\hline Paper & $\begin{array}{r}-0.4712^{* *} \\
(0.2015)\end{array}$ & $\begin{array}{c}1.0724^{*} \\
(0.567)\end{array}$ & $\begin{array}{l}-0.9484 \\
(1.0232)\end{array}$ & $\begin{array}{l}-0.0681 \\
(0.1107)\end{array}$ & $\begin{array}{r}-0.0111 \\
(0.0879)\end{array}$ & $\begin{array}{r}-5.335 \\
(19.1876)\end{array}$ & 0.73 & 5.91 & 0.1274 \\
\hline Textiles & $\begin{array}{r}-0.7502^{* * *} \\
(0.2705)\end{array}$ & $\begin{array}{c}2.4389^{*} \\
(1.284)\end{array}$ & $\begin{array}{r}3.1294 \\
(2.6318)\end{array}$ & $\begin{array}{r}-0.1738^{\star * *} \\
(0.0544)\end{array}$ & $\begin{array}{r}0.3466 \\
(0.2923)\end{array}$ & $\begin{array}{r}-49.3355^{\star *} \\
(21.5613)\end{array}$ & 0.79 & 8.35 & 0.2774 \\
\hline Wood & $\begin{array}{r}-0.5676 \\
(1.8578)\end{array}$ & $\begin{array}{r}-0.9473 \\
(1.054)\end{array}$ & $\begin{array}{r}-0.1751 \\
(6.9099)\end{array}$ & $\begin{array}{r}-0.1839 \\
(0.4739)\end{array}$ & $\begin{array}{r}0.0299 \\
(0.1620)\end{array}$ & $\begin{array}{r}68.6120 \\
(333.4143)\end{array}$ & 0.82 & 1.76 & 0.1677 \\
\hline
\end{tabular}


Table 7 Conditional $\beta$-convergence labour productivity, specified, fixed effects

\begin{tabular}{|c|c|c|c|c|c|c|c|c|c|}
\hline & $\beta$ & $\begin{array}{r}\text { Energy } \\
\text { Price }\end{array}$ & $\begin{array}{r}\text { Investment } \\
\text { share }\end{array}$ & Open & Balassa & $\begin{array}{c}\text { Value } \\
\text { added } \\
\text { share }\end{array}$ & $\mathrm{R}^{2}$ & F-stat & Implied $\lambda$ \\
\hline \multirow[t]{2}{*}{ Agriculture } & -0.0915 & $1.3847^{*}$ & $-0.7385^{*}$ & & & -0.2200 & 0.57 & 10.11 & 0.0192 \\
\hline & $(0.0595)$ & $(0.8037)$ & $(0.3722)$ & & & (2.8331) & & & \\
\hline \multirow[t]{2}{*}{ Services } & -0.1663 & -0.0038 & -0.0671 & & & 0.0866 & 0.83 & 16.20 & 0.0364 \\
\hline & $(0.1190)$ & $(0.0077)$ & $(0.1744)$ & & & $(0.8378)$ & & & \\
\hline \multirow[t]{2}{*}{ Transport } & $-0.5373^{\star * *}$ & 0.4192 & -0.4716 & & & $21.6825^{\star \star *}$ & 0.74 & 14.90 & 0.1541 \\
\hline & $(0.1551)$ & $(0.3580)$ & $(0.3011)$ & & & (4.0113) & & & \\
\hline \multirow[t]{2}{*}{ Chemicals } & $-0.6136^{\star \star *}$ & 0.5821 & -0.2272 & 0.0169 & 0.0073 & 58.5063 & 0.65 & 7.97 & 0.1902 \\
\hline & $(0.1461)$ & $(0.5868)$ & $(0.3363)$ & $(0.0278)$ & $(0.2747)$ & (15.9523) & & & \\
\hline \multirow[t]{2}{*}{ Food } & -0.1863 & 0.2232 & -0.6493 & -0.0319 & -0.1722 & -2.4415 & 0.42 & 2.72 & 0.0412 \\
\hline & $(0.1945)$ & (1.3284) & $(0.8939)$ & $(0.0831)$ & $(0.3118)$ & (6.809) & & & \\
\hline \multirow[t]{2}{*}{ Iron and Steel } & $-0.4745^{\star * *}$ & -2.3347 & $-0.8303^{\star * *}$ & 0.0411 & $0.3912^{* *}$ & -8.8493 & 0.64 & 7.40 & 0.1287 \\
\hline & $(0.1462)$ & (1.7504) & (0.2629) & $(0.0325)$ & $(0.1807)$ & (14.9038) & & & \\
\hline \multirow[t]{2}{*}{ Machinery } & -0.0094 & 0.1354 & -0.9026 & -0.0432 & 0.0462 & 4.8580 & 0.90 & 5.50 & -0.0663 \\
\hline & $(0.1600)$ & $(0.1573)$ & (1.3723) & $(0.0379)$ & $(0.4437)$ & (3.6685) & & & \\
\hline \multirow[t]{2}{*}{ Transport Equipment } & 0.3931 & $-2.9548^{* *}$ & -0.9192 & 0.0180 & 0.8165 & 5.9757 & 0.90 & 5.50 & -0.0663 \\
\hline & $(0.2863)$ & (1.3232) & $(0.6803)$ & $(0.0262)$ & $(0.6111)$ & (12.0548) & & & \\
\hline \multirow[t]{2}{*}{ Non-Ferrous Metals } & -0.1292 & 0.4453 & -0.0765 & 0.0192 & -0.0522 & $99.8361^{*}$ & 0.28 & 1.65 & 0.0277 \\
\hline & $(0.1562)$ & $(9.2387)$ & $(0.2227)$ & $(0.0231)$ & $(0.1578)$ & (59.341) & & & \\
\hline \multirow[t]{2}{*}{ Non-Metallic Minerals } & $-0.4089^{*}$ & 0.9708 & -0.7470 & 0.1170 & -0.3337 & 5.4763 & 0.36 & 2.15 & 0.1052 \\
\hline & $(0.2234)$ & $(5.8474)$ & $(0.7213)$ & $(0.1174)$ & $(0.3058)$ & $(21.5337)$ & & & \\
\hline \multirow[t]{2}{*}{ Paper } & $-0.3015^{\star}$ & 0.2964 & 0.2624 & $0.0966^{* *}$ & 0.0173 & $30.0144^{\star \star *}$ & 0.77 & 12.57 & 0.0718 \\
\hline & $(0.1693)$ & $(0.6340)$ & $(0.4128)$ & $(0.0450)$ & $(0.0381)$ & (5.6951) & & & \\
\hline \multirow[t]{2}{*}{ Textiles } & $-0.5183^{\star \star *}$ & $2.8072^{*}$ & 1.1598 & $-0.0426^{\star \star}$ & -0.1660 & $-23.1631^{\star *}$ & 0.69 & 8.41 & 0.1461 \\
\hline & (0.1459) & (1.5751) & $(1.2021)$ & $(0.0204)$ & $(0.1246)$ & (10.8028) & & & \\
\hline \multirow[t]{2}{*}{ Wood } & -0.1014 & -0.4483 & $-1.3205^{\star *}$ & 0.0001 & -0.0080 & 26.0902 & 0.78 & 11.51 & 0.0214 \\
\hline & $(0.1266)$ & $(1.6638)$ & (0.3985) & $(0.0348)$ & $(0.0210)$ & (17.3229) & & & \\
\hline
\end{tabular}

